\title{
Application of Irrigation Water Quality Indices and Multivariate Statistical Techniques for Surface Water Quality Assessments in the Northern Nile Delta, Egypt
}

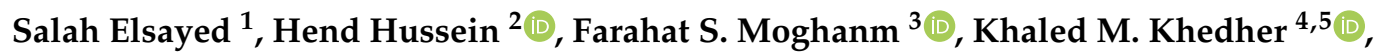 \\ Ebrahem M. Eid ${ }^{6,7, *(D)}$ and Mohamed Gad ${ }^{8}$ (D) \\ 1 Agricultural Engineering, Evaluation of Natural Resources Department, Environmental Studies and \\ Research Institute, University of Sadat City, Minufiya 32897, Egypt; salah.emam@esri.usc.edu.eg \\ 2 Geology Department, Faculty of Science, Damanhour University, Damanhour 22511, Egypt; \\ hendhussein@sci.dmu.edu.eg \\ 3 Soil and Water Department, Faculty of Agriculture, Kafrelsheikh University, Kafr El-Sheikh 33516, Egypt; \\ fsaadr@yahoo.ca \\ 4 Department of Civil Engineering, College of Engineering, King Khalid University, P.O. Box 394, \\ Abha 61321, Saudi Arabia; kkhedher@kku.edu.sa \\ 5 Department of Civil Engineering, High Institute of Technological Studies, Mrezgua University Campus, \\ Nabeul 8000, Tunisia \\ 6 Biology Department, College of Science, King Khalid University, P.O. Box 9004, Abha 61321, Saudi Arabia \\ 7 Botany Department, Faculty of Science, Kafrelsheikh University, Kafr El-Sheikh 33516, Egypt \\ 8 Hydrogeology, Evaluation of Natural Resources Department, Environmental Studies and Research Institute, \\ University of Sadat City, Minufiya 32897, Egypt; mohamed.gad@esri.usc.edu.eg \\ * Correspondence: ebrahem.eid@sci.kfs.edu.eg or eeid@kku.edu.sa or ebrahem.eid@gmail.com; \\ Tel.: +966-55-2717026; Fax: +966-17-2418205
}

Received: 25 September 2020; Accepted: 18 November 2020; Published: 24 November 2020

\begin{abstract}
Under sustainable development conditions, the water quality of irrigation systems is a complex issue which involves the combined effects of several surface water management parameters. Therefore, this work aims to enhance the surface water quality assessment and geochemical controlling mechanisms and to assess the validation of surface water networks for irrigation using six Water Quality Indices (WQIs) supported by multivariate modelling techniques, such as Principal Component Regression (PCR), Support Vector Machine Regression (SVMR) and Stepwise Multiple Linear Regression (SMLR). A total of 110 surface water samples from a network of surface water cannels during the summers of 2018 and 2019 were collected for this research and standard analytical techniques were used to measure 21 physical and chemical parameters. The physicochemical properties revealed that the major ions concentrations were reported in the following order: $\mathrm{Ca}^{2+}>\mathrm{Na}^{+}>\mathrm{Mg}^{2+}>\mathrm{K}^{+}$ and alkalinity $>\mathrm{SO}_{4}{ }^{2-}>\mathrm{Cl}^{-}>\mathrm{NO}_{3}{ }^{-}>\mathrm{F}^{-}$. The trace elements concentrations were reported in the following order: $\mathrm{Fe}>\mathrm{Mn}>\mathrm{B}>\mathrm{Cr}>\mathrm{Pb}>\mathrm{Ni}>\mathrm{Cu}>\mathrm{Zn}>\mathrm{Cd}$. The surface water belongs to the $\mathrm{Ca}^{2+}-\mathrm{Mg}^{2+}-\mathrm{HCO}_{3}{ }^{-}$and $\mathrm{Ca}^{2+}-\mathrm{Mg}^{2+}-\mathrm{Cl}^{-}-\mathrm{SO}_{4}{ }^{2-}$ water types, under a stress of silicate weathering and reverse ion exchange process. The computation of WQI values across two years revealed that $82 \%$ of samples represent a high class and the remaining $18 \%$ constitute a medium class of water quality for irrigation use with respect to the Irrigation Water Quality (IWQ) value, while the Sodium Percentage (Na\%) values across two years indicated that $96 \%$ of samples fell into in a healthy class and $4 \%$ fell into in a permissible class for irrigation. In addition, the Sodium Absorption Ratio (SAR), Permeability Index (PI), Kelley Index (KI) and Residual Sodium Carbonate (RSC) values revealed that all surface water samples were appropriate for irrigation use. The PCR and SVMR indicated accurate and robust models that predict the six WQIs in both datasets of the calibration (Cal.) and validation (Val.), with $R^{2}$ values varying from 0.48 to 0.99 . The SMLR presented estimated the six WQIs well,
\end{abstract}


with an $R^{2}$ value that ranged from 0.66 to 0.99 . In conclusion, WQIs and multivariate statistical analyses are effective and applicable for assessing the surface water quality. The PCR, SVMR and SMLR models provided robust and reliable estimates of the different indices and showed the highest $R^{2}$ and the highest slopes values close to 1.00, as well as minimum values of RMSE in all models.

Keywords: Egypt; irrigation water quality; Nile Delta; PCR model; SMLR model; surface water

\section{Introduction}

In the northern Nile Delta (Egypt), surface water is the main water supply for agricultural use, and the ongoing growth of production requires additional fresh water for irrigation. Agriculture developments in Egypt mainly depend on supplying irrigation water through irrigation canals; therefore, farmers in the northern part of the Nile Delta are strongly using surface water networks to irrigate their fields because these networks are considered to be the only source of irrigation in the region [1-3]. Agriculture is a significant sector in Egypt, contributing approximately $24.5 \%$ to the gross domestic production of the country, and constitutes the main occupation in the study area $[4,5]$. However, in this study area, excessive agricultural practices, geogenic pollution, the extreme increases in population and increased urbanisation have placed contentious pressure on surface water resources and have led to potentially negative impacts on the physicochemical characteristics of water and water quality [6,7]. Preliminary knowledge on water types, different geochemical processes, and water classification for irrigation is provided by surface water chemistry based on hydrochemical parameters. The chemistry of the water with respect to geochemical criteria offers basic knowledge on water facies, different geochemical processes, and water characterization for irrigation purposes. The imitative technique, Gibbs Diagram [8], is an applicable and commonly used method for defining the main geochemical control processes driving the chemical composition of surface water [9-11].

The chemistry of surface water based on hydrochemical benchmarks supplies updated knowledge on water types, diverse geochemical processes and water classifications [12-15]. Therefore, the integration of surface water chemistry and geochemical characteristics offers a valuable context for analysing trends, identifying unique environmental problems, and exchanging information about water sources, geochemical processes, water quality and water susceptibility to contamination [16-18].

The Irrigation Water Quality depends on its quantity and the type of salts that occur in the water. The most important issues related to deterioration of water quality are increased salinity, reduced permeability, and exposure to particularly toxic ions [19]. Therefore, assessments of the quality for irrigation usages are defined by its physicochemical parameters [20] using imitative techniques as US Salinity Laboratory [21] and Wilcox Diagram [22]. These techniques are applicable and commonly utilized to estimate water quality for irrigation usages. Furthermore, the aforementioned techniques to assess the water quality, Water Quality Indices (WQIs) are used to determine the quality of water, which present a useful interpretation of the quality of water used for irrigation. The individual water quality parameter is not adequate to estimate the validation of water for irrigation because it can be restrictive and may often produce inadequate performance in the evaluation [23]. The weighted score of each variable was used by several other studies to suggest a water quality index $[24,25]$. Based on experience and judgement, WQIs that include the Irrigation Water Quality (IWQ), $\mathrm{Na} \%, \mathrm{SAR}$, $\mathrm{PI}, \mathrm{KI}$ and RSC can meet the requirements for proper monitoring and evaluation of irrigation water suitability [26-29]. In the development of WQIs, the key concept is to include several variables in a single numeric value. The goal of the WQIs is to identify the waters in relation to their potential uses, chemical and physical characteristics, and to control their allocations [30,31]. For this reason, the analytical parameters need to be weighted and aggregated. Therefore, WQIs are used to evaluate water quality in this study. For example, the IWQ is a powerful monitoring tool to understand the 
combined effects of various physicochemical parameters with respect to trace elements according to the weight and rate of each parameter and can indicate the quality of water used for irrigation $[19,32]$. The IWQ incorporates the influence of five hazard groups, which are integrated to a single value as (output) that represents the quality of water used for irrigation [33-36]. Dutta et al. [37] found that water quality index values showed high levels of contamination in the water body tested, making it unacceptable for any practical reason in the Nag River. Elumalai et al. [38] found that several WQIs such as EC, Na\%, SAR, PI and RSC exhibited good performance to estimate water quality levels for irrigation in Luvuvhu Catchment, Limpopo, South Africa.

In addition to WQIs, in recent years multivariate statistical approaches have been commonly used and are impartial tools that can expose sample associations and/or variables based on meaningful classifications of surface water and hydrochemical variables. Although WQIs are significant tools for assessing water quality in hydrochemical studies, multivariate statistical analysis are often commonly used to evaluate water quality such as Cluster Analysis (CA) $[39,40]$. Therefore, CA is a multivariate technique to classify the physicochemical parameters into classes according to the interrelation between the chemical constituencies of surface water resources [41].

The essential tools for understanding the characteristics and actions of surface water quality are geochemical analyses and multivariate analyses, in particular the several researches carried out worldwide through them to understand the relationship between water quality and water processes, and, specifically, processes related to contaminated surface water [42-44].

Over the past decade, several research initiatives have been aimed at creating and enhancing water quality prediction models [45-47]. Recently, machine learning and data-driven results have shown promising results in the development of precise water quality estimation models [48,49]. Therefore, multivariable statistical regression methods, including the PCR, SVMR and SMLR, were tested as alternative approaches for predicting WQIs for irrigation. These approaches incorporate multiple independent variables into estimation models used to predict a single dependent variable [50-52]. The PCR is a linear regression that first decomposes data into a representation of the maximum variation and aims to optimize the model's estimated capacity; then, the optimum number of the latent factors is reversed against the response variable [52]. In a small sample size, the regression can screen for weighting factors with low collinearity [53]. The PCR is widely used to develop predictive models between the hyper spectral responses of the analysed samples in the in-situ canopy [54-57].

The SVMR maps variable input into a high-dimensional feature space using a kernel function and can therefore handle high-dimensional input vectors. The SVMR can therefore provide a more rational alternative than the linear approach [58]. The SVMR algorithm is a universal theory of machine learning for pattern classification and recognition. The SVMR model can solve either regression or classification problems, and is able to map low-dimensional nonlinear input to high-dimensional linear output with excellent outcomes [59]. The SMLR is used to determine single variables output data responses in more variables as input data [60-62]. SMLR is also used to determine the most influential independent variables by accounting for the highest degree of variability in the measured parameters $[62,63]$.

To the best of our knowledge, the issue on predicting of IWQS using PCR, SVMR and SMLR models, based on major ions and trace elements, has not been addressed thus far. Therefore, this study focused on evaluating the performance of these models for estimating IWQs for two years as new approach methods. Thus, the targets of this work are: (i) to identify surface water facies and the geochemical controlling mechanisms that affecting on water quality; (ii) to assess the validation of surface water for irrigation using WQIs; (iii) to evaluate the efficiency of the PCR and SVMR models to predict WQIs for irrigation based on chemical elements and; (iv) to evaluate the efficiency of the SMLR models to predict WQIs for irrigation based on the most influential chemical elements. 


\section{Material and Methods}

\subsection{Sampling and Analyses}

The investigated region is located in the northern part of the Nile Delta, and is enclosed between the Rosetta and Damietta Branches, which are located between $30^{\circ} 21^{\prime} 40^{\prime \prime}$ and $31^{\circ} 18^{\prime} 40^{\prime \prime} \mathrm{N}$ latitudes and $30^{\circ} 59^{\prime} 38^{\prime \prime}$ and $31^{\circ} 36^{\prime} 00^{\prime \prime}$ E longitudes (Figure 1). In this research, 110 surface water samples were collected during the summers of 2018 and 2019. The samples were collected in $500 \mathrm{~mL}$ polyethylene bottles and they were stored in a $4{ }^{\circ} \mathrm{C}$ refrigerator, then they were analysed using standard analytical techniques [64]. The chemical analysis was carried out using various apparatuses and techniques. The $\mathrm{pH}$, TDS, EC, were measured in situ using $\mathrm{pH} / \mathrm{EC} / \mathrm{TDS}$ meter (Hanna HI 9811-5). The flame photometer (PFP7 U.K.) were used to analysed $\mathrm{K}^{+}, \mathrm{Na}^{+}$, while EDTA titration (Titrimetric method) were used to analysed $\mathrm{Ca}^{2+}, \mathrm{Mg}^{2+}, \mathrm{Cl}^{-}$and alkalinity. Alkalinity was referred to the $\mathrm{HCO}_{3}{ }^{-}$since $\mathrm{CO}_{3}{ }^{2-}$ was below the detection limit. In addition, $\mathrm{SO}_{4}{ }^{2-}$ and $\mathrm{NO}_{3}{ }^{-}$were measured using UV/Visible Spectrophotometer. B, Cd, Cr, Cu, F, Fe, Mn, Ni, Pb and $\mathrm{Zn}$ were analysed using atomic absorption spectrometer (FAAS-Zeeman AASZ-5000, Hitachi, Ibaraki Prefecture, Japan). The analytical results of all elements over two years were presented in Supplementary Tables S1 and S2.

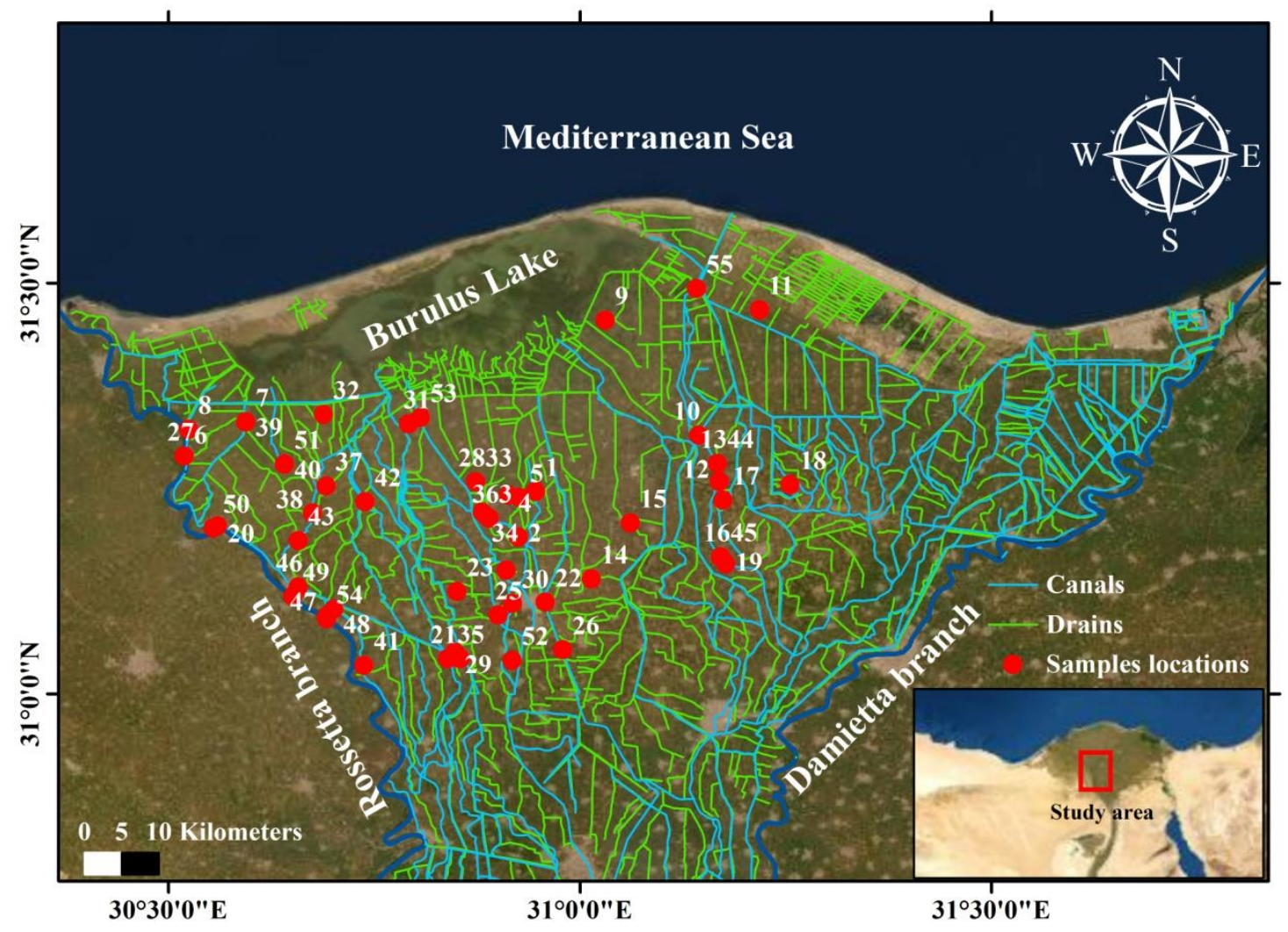

Figure 1. Location map of surface water networks and the collected samples.

\subsection{Water Quality Indices (WQIs)}

Surface water appropriability for irrigation was calculated based on the referenced WQIs including the IWQ, Na\%, SAR, SSP, PI, KI and RSC values (Table 1), with respect to the measured water parameters. The numerical effects of the specific values and units of various water quality parameters were transformed into a single value by an extant mathematical method [65], which is illustrated in the following sections. 
Table 1. Water quality indices for irrigation, formula and references. * All Water Quality Indices (WQIs) are estimated in meq/L except Irrigation Water Quality (IWQ), which is estimated in $\mathrm{mg} / \mathrm{L}$.

\begin{tabular}{ccc}
\hline Water Quality Indices (WQIs) & Formula & References \\
\hline Irrigation Water Quality & $\mathrm{IWQ}=\sum_{\mathrm{i}=1}^{5} \mathrm{G}_{\mathrm{i}}$ & {$[66]$} \\
\hline Sodium Percentage * & $\mathrm{Na} \%=\left[\left(\mathrm{Na}^{+}+\mathrm{K}^{+}\right) /\left(\mathrm{Ca}^{2+}+\mathrm{Mg}^{2+}+\mathrm{Na}^{+}+\mathrm{K}^{+}\right)\right] \times 100$ & {$[67]$} \\
\hline Sodium Absorption Ratio & $\mathrm{SAR}=\left[\mathrm{Na}^{+} / \sqrt{\left(\mathrm{Ca}^{2+}+\mathrm{Mg}^{2+}\right) / 2}\right] \times 100$ & {$[68]$} \\
\hline Permeability Index & $\left.\mathrm{PI}=\left[\left(\mathrm{Na}^{+}+\mathrm{K}^{+}+\sqrt{\mathrm{Alkalinity}}\right]\right) /\left(\mathrm{Ca}^{2+}+\mathrm{Mg}^{2+}+\mathrm{Na}^{+}+\mathrm{K}^{+}\right)\right] \times 100$ & {$[69]$} \\
\hline Kelley Index * & $\mathrm{KI}=\mathrm{Na}^{+} /\left(\mathrm{Ca}^{2+}+\mathrm{Mg}^{2+}\right)$ & {$[70]$} \\
\hline Residual Sodium Carbonate & $\mathrm{RSC}=\left[(\right.$ Alkalinity $\left.)-\left(\mathrm{Ca}^{2+}+\mathrm{Mg}^{2+}\right)\right]$ & {$[68]$} \\
\hline
\end{tabular}

\subsubsection{Indexing Approach}

The IWQ is a useful index that describes the cumulative effect of the five hazard groups on the quality of water used for irrigation. These groups include the danger of salinity, the threat of permeability, the basic toxicity of the ions, the toxicity of the trace elements and the different consequences [24,66]. To compute the IWQ, a weight, ranging from 1 to 5 , was assigned to each group, and then ratings were assigned for individual physicochemical parameters. The IWQ is assigned with respect to the weight and rating of the individual physicochemical data. The IWQ is identified by documented mathematical methods according to Equation (1), as follows:

$$
I W Q=\sum_{i=1}^{5} G_{i}
$$

where, $i$ is the cumulative index and $G$ is the input of each hazard groups. The salinity hazard $\left(G_{1}\right)$ is the first category expressed by an EC value according to Equation (2), as follows:

$$
G_{1}=w_{1} r_{1}
$$

where $w_{1}$ is the group weight and $r$ is the parameter ranking. The second hazard group is the risk of permeability $\left(G_{2}\right)$, which is expressed by the combined relationship between EC and SAR (Supplementary Table S3), according to Equation (3), as follows:

$$
G_{2}=w_{2} r_{2}
$$

where, $w_{2}$ and $r_{2}$ are the weight and rating of this group, respectively. The third group is the toxicity of specific ion $\left(G_{3}\right)$, which includes the SAR and the concentration of $\mathrm{Cl}$ and $\mathrm{B}$ ions in water, and is calculated according to a weighted average of these parameters, as the following Equation (4):

$$
G_{3}=\frac{w_{3}}{3} \sum_{j=3}^{3} r_{j}
$$

where, $j$ is the cumulative index, $w$ is the group weight, and $r$ is the ranking of each parameter. A toxicity of trace elements represent the fourth group $\left(G_{4}\right)$, which is estimated as a weighted average for the individual trace elements (Supplementary Table S4), according to Equation (5), as follows:

$$
G_{4}=\frac{w_{4}}{N} \sum_{k=1}^{N} r_{k}
$$

where, $k$ is the cumulative index, $N$ is the number of individual trace elements, $w$ is the group weight, and $r$ represent the ranking of each individual parameter. The final group is the miscellaneous effects 
to sensitive crops $\left(G_{5}\right)$, which is represented by the concentration of nitrate-nitrogen, alkalinity, and $\mathrm{pH}$ as a weighted average and is formulated by Equation (6), as follows:

$$
G_{5}=\frac{w_{5}}{3} \sum_{m=1}^{3} r_{m}
$$

where, $m$ is the cumulative index, $w$ is the group weight, and $r$ is the ranking of each parameter. However, the WQIs, including $\mathrm{Na} \%$, SAR, PI, KI and RSC, were calculated based on recorded mathematical equations, which convert water quality data into a numerical value, and describe the irrigation quality of water.

\subsection{Data Analysis}

The geochemical controlling factors and the characterization of surface water were evaluated using Gibbs Diagram, United States Salinity Laborator (USSL) Diagram and Wilcox Diagram with Geochemist's Microsoft Excel Worksheet over two years. The analytical results obtained were presented as WQIs and were imported to ArcGIS version 10 and processed to determine surface water quality parameters for irrigation suitability over two years. A statistical description (range, mean and standard error) of the physicochemical parameters was calculated using SPSS version 22 (SPSS Inc., Chicago, IL, USA). The relationships between major physicochemical parameters was processed using Microsoft Excel, in order to recognize the geochemical processes and controlling mechanisms that effect on Irrigation Water Quality. Multivariate statistical analysis including Cluster Analysis (CA) is commonly used to assess water quality for enhancing the classification of physicochemical parameters in water through the reduction in common patterns of chemical analyses. The CA was applied using Ward method of describing the similarities between the two clusters to identify the different geochemical groups with similar content of physicochemical parameters in surface water. The CA was established across two years by using PAST software (V. 3.25).

Using simple regressions (Sigma Plot 12.0), a Pearson's correlation coefficient was used to assess the relationships of WQIs with chemical elements at significance values at 0.05 and 0.01 across two years. A multivariate statistical analysis using the PCR and SVMR was developed with unscramble $\mathrm{X}$ version 10.2 (CAMO Software AS, Oslo, Norway). Using the major ions and trace elements as input parameters, PCR and SVMR were used to build predictive models of the WQIs. To simulate and predict WQIs, a time series of 110 surface water samples were used. For the PCR and SVMR models construction, the data set of all water samples was segregated at random into two portions for progressions as calibration (Cal.) and validation (Val.) by taking into consideration 75 and 25 per-cents correspondingly.

The two models of the PCR and SVMR are an ideal method of calibration (Cal.) for predicting a single dependent variable (e.g., Sodium Percentage $(\mathrm{Na} \%)$ based on multiple independent variables (e.g., $\mathrm{Na}^{+}, \mathrm{K}^{+}, \mathrm{Ca}^{2+}$ and $\mathrm{Mg}^{2+}$ ). The Cal. and validation models (Val.) for $\mathrm{Na} \%, \mathrm{SAR}, \mathrm{PI}, \mathrm{KI}$ and RSC in the PCR models were built based on several major ions and are described by the equations in Table 1. However, the Cal. and Val. models of the IWQ were built based on all major ions with respect to the trace elements. For the PCR models, the optimal number of latent factors was selected without overfitting to reflect the Cal. data. To improve the performance of the models, a 10-fold cross-validation of the data was carried out.

To construct the SMLR models of WQIs, SPSS version 22 (SPSS Inc., Chicago, IL, USA) was used. The major ions and trace elements for IWQ and the major ions for the other five indices are indicated by the equations in Table 1 and were analysed by the SMLR model to indicate the most influential parameters that account for the greatest number of variability parameters according to Gad et al. [71]. Only the major ion or trace elements, which remained significant in the models at $p$-values $<0.05$, were maintained at each level [72]. In addition, to establish the SMLR models, the data 
set of 110 samples over two years was divided at random into two portions for progressions as calibration (Cal.) and validation (Val.) by taking into consideration 75 and 25 per-cent, respectively.

The equation for SMLR can be shown as:

$$
Y=\beta_{0}+\beta_{1} X_{1}+\beta_{2} X_{2}+\beta_{3} X_{3}+\ldots \beta_{m} X_{m}
$$

where: $Y=$ output parameter such as WQIs and PIs, $\beta_{0}=$ constant parameter, $\beta_{1}$ to $\beta_{m}=$ coefficients of control of cations and ions parameters, and $X_{1}$ to $X_{m}=$ control of cations and ions parameters. The performance of the Cal. and Val. models for the PCR, SVMR and SMLR were indicated by the adjusted $R^{2}$, root mean square errors (RMSE) and the slopes of the relationships of the observed and predicted WQIs data.

\section{Results and Discussion}

\subsection{Physicochemical Parameters and Water Facies}

The physicochemical parameters, including cations, anions and trace elements, at 110 surface water points during two years from the northern Nile Delta basin are presented in Table 2, along with the range, mean, and standard error values. The results of the physicochemical parameters across two years revealed that the $\mathrm{pH}$ values ranged from 7.1 to 8.7 , indicating high alkalinity $\mathrm{pH}(>6.5)$, which means that these waters are validated for irrigation according to Ayers and Westcot [36]. The EC values ranged from 334.7 to $791.0 \mu \mathrm{S} / \mathrm{cm}$, which indicated a freshwater type and were in the optimal level for agriculture purposes. The low EC values indicated fast soil-water ion exchange, insoluble geologic rocks and mineral forms, and little solute dissolution. The $\mathrm{Ca}^{2+}$ concentration of the collected samples ranged from 18.4 to $64.6 \mathrm{mg} / \mathrm{L}$, which indicates it is the dominant cation, followed by $\mathrm{Na}^{+}$, which ranged from 11.8 to $55.0 \mathrm{mg} / \mathrm{L}$ and was the second most dominant cation; these values are acceptable for irrigation according to Ayers and Westcot [36]. The alkalinity content ranged between 110.7 and $278.3 \mathrm{mg} / \mathrm{L}$, indicating that it was the dominant anion, followed by $\mathrm{SO}_{4}{ }^{2-}$, which varied from 21.4 to $104.1 \mathrm{mg} / \mathrm{L}$, which is within the acceptable limit for irrigation according to FAO [73]. The $\mathrm{Cl}^{-}$ contents ranged from 3.8 to $55.0 \mathrm{mg} / \mathrm{L}$, with mean value of $29.4 \mathrm{mg} / \mathrm{L}$ and were within acceptable limits for irrigation $(0.0-1050.0 \mathrm{mg} / \mathrm{L})$ according to $\mathrm{FAO}$ [73]. The $\mathrm{NO}_{3}{ }^{-}$contents ranged between 0.5 and $4.4 \mathrm{mg} / \mathrm{L}$, indicating a very low concentration with no impact on irrigation water suitability. Using agrochemicals for longer periods can possibly affect the portability of groundwater due to increased concentration of ions and poor flushing [74].

The concentrations of trace elements occurred in the following sequence: $\mathrm{Fe}>\mathrm{Mn}>\mathrm{B}>\mathrm{Cr}>$ $\mathrm{Pb}>\mathrm{Ni}>\mathrm{Cu}>\mathrm{Zn}>\mathrm{Cd}[66]$. The low concentrations of trace elements indicated that there were no significant effects on the irrigation water suitability [48]. For example, El-Bana [75], El-Bana et al. [76] and El Bouraie et al. [7] studied the temporal variation of $\mathrm{Al}, \mathrm{Ba}, \mathrm{Cd}, \mathrm{Co}, \mathrm{Cr}, \mathrm{Cu}, \mathrm{Fe}, \mathrm{Mn}, \mathrm{Ni}, \mathrm{Pb}$ and $\mathrm{Zn}$ in Nile River water in the northern Nile Delta and the effects of these elements on the water quality. They concluded that, according to FAO [73], the trace elements concentrations were mainly within acceptable to permissible limits for irrigation.

The average ion concentrations of the surface water samples occurred in the following order: $\mathrm{Ca}^{2+}>\mathrm{Na}^{+}>\mathrm{Mg}^{2+}>\mathrm{K}^{+}$and alkalinity $>\mathrm{SO}_{4}{ }^{2-}>\mathrm{Cl}^{-}>\mathrm{NO}_{3}{ }^{-}>\mathrm{F}^{-}$, which indicate that the waters are in the first stage of evolution and are recharging from the Nile River. In the study region, the higher amount of $\mathrm{Ca}^{2+}$ concentrations suggested that the release of $\mathrm{Ca}^{2+}$ by weathering silicate minerals [77]. Furthermore, alkalinity values in the samples collected registered their highest from surface water, which may have been derived from atmospheric silicate weathering and carbonate dissolution [78].

According to the previous work of Gad et al. [71], the water facies in this region are belongs to $\mathrm{Ca}^{2+}-\mathrm{Mg}^{2+}-\mathrm{HCO}_{3}{ }^{-}$and $\mathrm{Ca}^{2+}-\mathrm{Mg}^{2+}-\mathrm{Cl}^{-}-\mathrm{SO}_{4}{ }^{2-}$, which was affected by rock water interaction processes and weathering. The major ions are powerful tools for detecting solute sources; the wide ranges of the 
ions in the surface water samples indicate the effect of several recharging sources, e.g., surface canals, anthropogenic practise, drains and overuse of fertilizers and pesticides [17].

Table 2. Statistical analysis of the physicochemical parameters over two years.

\begin{tabular}{ccccc}
\hline \multirow{2}{*}{ Parameters } & \multicolumn{2}{c}{ Range } & \multicolumn{2}{c}{ Mean \pm Standard Error } \\
\cline { 2 - 5 } & First Year & Second Year & First Year & Second Year \\
\hline $\mathrm{pH}$ & $7.1-8.5$ & $7.2-8.7$ & $7.81 \pm 0.03$ & $8.00 \pm 0.29$ \\
$\mathrm{TDS}$ & $214.2-460.6$ & $260.0-506.0$ & $314.43 \pm 11.17$ & $359.71 \pm 88.90$ \\
$\mathrm{EC}$ & $334.7-719.7$ & $406.0-791.0$ & $491.31 \pm 17.45$ & $562.09 \pm 138.87$ \\
$\mathrm{~K}^{+}$ & $3.1-9.5$ & $4.5-11.2$ & $6.01 \pm 0.24$ & $7.39 \pm 1.98$ \\
$\mathrm{Na}^{+}$ & $11.8-48.9$ & $15.0-55.0$ & $27.91 \pm 1.46$ & $32.51 \pm 11.56$ \\
$\mathrm{Mg}^{2+}$ & $6.3-23.8$ & $8.1-25.0$ & $14.22 \pm 0.54$ & $16.97 \pm 4.27$ \\
$\mathrm{Ca}^{2+}$ & $18.4-58.6$ & $22.6-64.6$ & $34.31 \pm 1.31$ & $39.56 \pm 10.98$ \\
$\mathrm{Cl}^{-}$ & $3.8-47.6$ & $4.0-55.0$ & $22.46 \pm 1.37$ & $28.80 \pm 12.21$ \\
$\mathrm{SO}_{4}^{2-}$ & $21.4-93.9$ & $26.2-104.1$ & $40.31 \pm 2.20$ & $52.10 \pm 18.06$ \\
$\mathrm{Alkalinity}^{2-}$ & $110.7-254.2$ & $118.0-278.3$ & $169.18 \pm 5.91$ & $184.29 \pm 44.59$ \\
$\mathrm{NO}^{-}$ & $0.5-4.3$ & $0.8-4.4$ & $1.46 \pm 0.07$ & $1.51 \pm 0.58$ \\
$\mathrm{~F}^{-}$ & $0.11-0.68$ & $0.10-0.70$ & $0.270 \pm 0.02$ & $0.265 \pm 0.168$ \\
$\mathrm{~B}$ & $0.01-0.40$ & $0.01-0.20$ & $0.10 \pm 0.01$ & $0.07 \pm 0.04$ \\
$\mathrm{Cd}$ & $0.0002-0.0310$ & $0.0001-0.0009$ & $0.005 \pm 0.001$ & $0.001 \pm 0.000$ \\
$\mathrm{Cr}$ & $0.003-0.310$ & $0.005-0.100$ & $0.050 \pm 0.007$ & $0.047 \pm 0.020$ \\
$\mathrm{Cu}$ & $0.001-0.020$ & $0.001-0.030$ & $0.008 \pm 0.0005$ & $0.009 \pm 0.005$ \\
$\mathrm{Fe}$ & $0.04-1.17$ & $0.05-0.70$ & $0.220 \pm 0.02$ & $0.206 \pm 0.157$ \\
$\mathrm{Mn}$ & $0.01-0.43$ & $0.01-0.45$ & $0.090 \pm 0.01$ & $0.105 \pm 0.087$ \\
$\mathrm{Ni}$ & $0.001-0.040$ & $0.001-0.050$ & $0.010 \pm 0.001$ & $0.017 \pm 0.017$ \\
$\mathrm{~Pb}$ & $0.001-0.310$ & $0.001-0.090$ & $0.04 \pm 0.012$ & $0.021 \pm 0.019$ \\
$\mathrm{Zn}$ & $0.001-0.210$ & $0.001-0.008$ & $0.02 \pm 0.007$ & $0.003 \pm 0.002$ \\
\hline
\end{tabular}

Each element is expressed in $\mathrm{mg} / \mathrm{L}$ except $\mathrm{pH}$ and $\mathrm{EC}(\mu \mathrm{S} / \mathrm{cm})$.

\subsection{Geochemical Controlling Mechanisms}

According to geochemical data plot on the Gibbs Diagram in the two-years through the relation of TDS vs. the ratios $\left(\mathrm{Na}^{+}+\mathrm{K}^{+}\right) /\left(\mathrm{Na}^{+}+\mathrm{K}^{+}+\mathrm{Ca}^{2+}\right)$ and $\mathrm{Cl}^{-} /\left(\mathrm{Cl}^{-}+\right.$Alkalinity), the surface water samples were distributed in the rock dominance and weathering fields (Figure 2). The key factors regulating pathways that affect surface water geochemistry in the investigated area are assumed to be these processes. The influence of these geochemical processes on the Irrigation Water Quality of the Nile River over two years has not been significant, resulting in the high self-assimilation capacity of river water. 


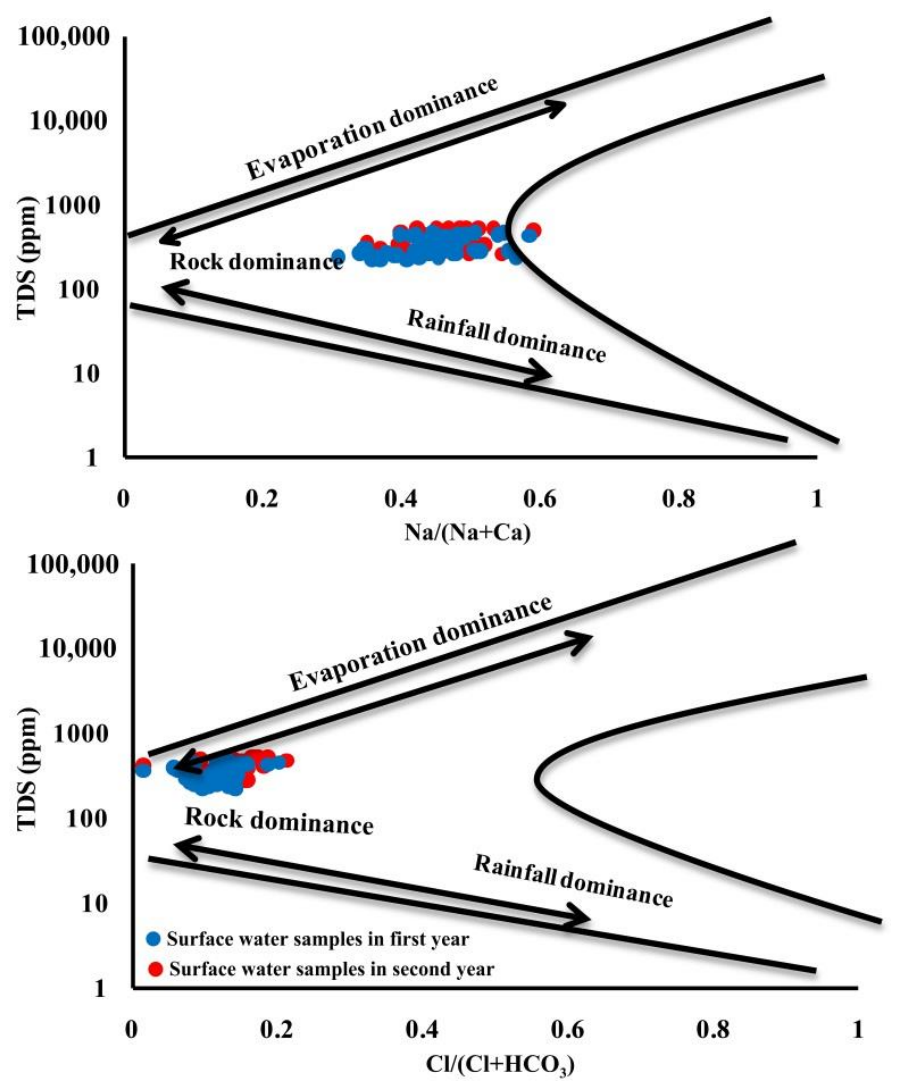

Figure 2. The geochemical controlling factors for surface water samples over two years according to the Gibbs Diagram.

The geochemical processes and their control mechanisms affected the evolution of surface water quality and their suitability for irrigation. The similarities between the main analysed physicochemical components of the collected surface water samples were established (Figure 3). In semi-arid regions such as the study area, the relationship between $\mathrm{Na}^{+}$vs. $\mathrm{Cl}^{-}$is generally important in identifying the pathways to salinity acquisition (Figure 3a). The collected surface water samples fall below the halite dissolution line with a strong determination coefficient $\left(R^{2}=0.60\right.$ and 0.63$)$, suggesting the process of ion exchange or silicate mineral weathering. The $\left(\mathrm{Ca}^{2+}+\mathrm{Mg}^{2+}\right)-\left(\mathrm{HCO}_{3}{ }^{-}+\mathrm{SO}_{4}{ }^{2-}\right) \mathrm{vs}^{2} \mathrm{Na}^{+}-\mathrm{Cl}^{-}$ plot showed that the surface water samples fell on a best fit line with a high determination coefficient $\left(R^{2}=0.94\right)$ (Figure 3c). The relationship between $\mathrm{Na}^{+}$vs. $\left(\mathrm{Ca}^{2+}+\mathrm{Mg}^{2+}\right)$ presented that the samples fell below the equimolar line (Figure $3 \mathrm{~d}$ ), which reflects the reverse ion exchange process. The relationship of $\left(\mathrm{SO}_{4}{ }^{2-}+\mathrm{HCO}_{3}{ }^{-}\right)$vs. $\left(\mathrm{Ca}^{2+}+\mathrm{Mg}^{2+}\right)$ revealed that most water samples fall above the equimolar line (Figure $3 \mathrm{e}$ ), which revealed the silicate weathering process. The plot of $\mathrm{Na}^{+} \mathrm{vs} \mathrm{SO}_{4}{ }^{2-}$ (Figure $3 \mathrm{f}$ ) presented a positive relationship with, $R^{2}=0.42$ and 0.47 . Subrahmanyam and Yadaiah [79] found that $\mathrm{Ca}^{2+}$ may have resulted from the dissolution of anhydrite minerals, dolomite and gypsum in surface water. The exchange of cations can also increase the surface water concentration of $\mathrm{Ca}^{2+}$. In the collected surface water samples, toxic waste and illegal sewage dumping can also lead to higher $\mathrm{Ca}^{2+}$ concentration. 

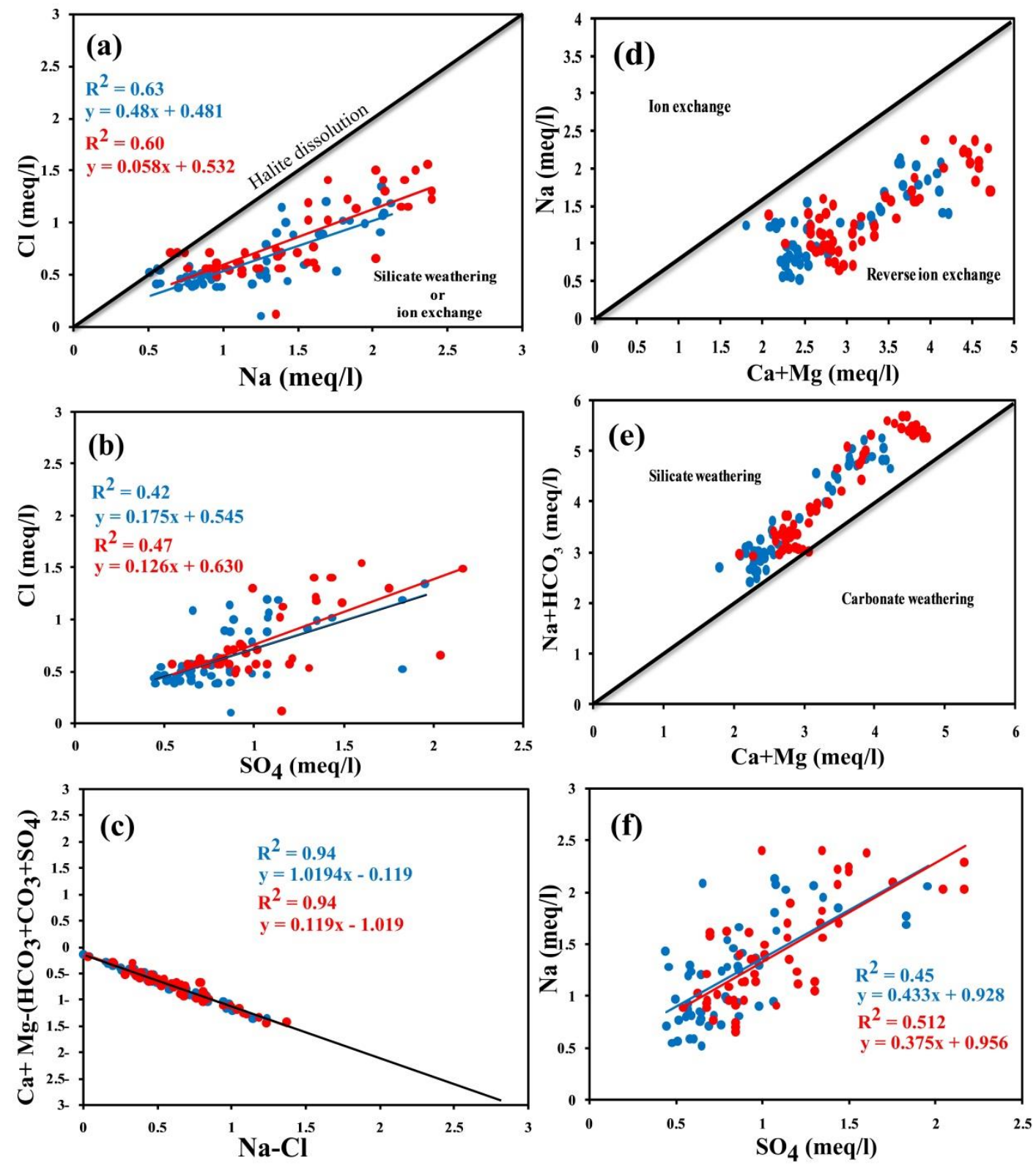

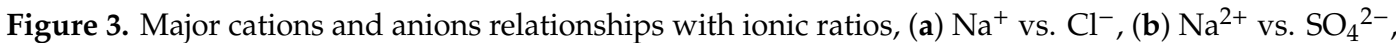
(c) $\mathrm{Na}^{+}-\mathrm{Cl}^{-}$vs. $\mathrm{Ca}^{2+}+\mathrm{Mg}^{2+}-\left(\mathrm{HCO}_{3}{ }^{2-}+\mathrm{CO}_{3}{ }^{2-}+\mathrm{SO}_{4}{ }^{2-}\right)$, (d) $\mathrm{Na}^{+}$vs. $\mathrm{Ca}^{2+}+\mathrm{Mg}^{2+},\left(\right.$ e) $\mathrm{Ca}^{2+}+\mathrm{Mg}^{2+}$ vs. $\mathrm{Na}^{+}+\mathrm{HCO}_{3}{ }^{2-}$, (f) $\mathrm{Na}^{+}$vs. $\mathrm{SO}_{4}{ }^{2-}$ of surface water samples over two years.

\subsection{Cluster Analysis}

The CA was used to identify the reasons that were responsible for water quality changes converting the initial variables into a new set of variables that the classification of the physicochemical parameters associated with water. The CA results for the major ions revealed that two types of clustering included EC and TDS in the same cluster (Cluster 1). The other parameters, $\mathrm{K}^{+}, \mathrm{Na}^{+}, \mathrm{Ca}^{2+}, \mathrm{Mg}^{2+}, \mathrm{pH}$, alkalinity, $\mathrm{Cl}^{-}, \mathrm{SO}_{4}{ }^{2-}$ and $\mathrm{NO}_{3}{ }^{-}$were in another cluster (Cluster II). Cluster II was further divided into two sub-clusters that represented $\mathrm{pH}$ and alkalinity in one group and $\mathrm{K}^{+}, \mathrm{Na}^{+}, \mathrm{Ca}^{2+}, \mathrm{Mg}^{2+}, \mathrm{Cl}^{-}, \mathrm{SO}_{4}{ }^{2-}$ and $\mathrm{NO}_{3}{ }^{-}$in the second group (Figure 4a). According to the cluster analysis of major physicochemical parameters, surface water in the investigated area was classified into $\mathrm{HCO}_{3}{ }^{-}$as a dominant anion and $\mathrm{Ca}^{2+}, \mathrm{Na}^{+}$and $\mathrm{Mg}^{2+}$ as dominant cations respectively, which reflects fresh water in the first stage of evolution and suitability for irrigation. 




Figure 4. Cluster Analysis (CA) for surface water physicochemical parameters across two years: (a) CA for major ions and (b) CA for trace elements.

The CA of the physicochemical parameters with respect to trace elements in the studied area (Figure $4 \mathrm{~b}$ ) revealed that the high contributions of Fe and Mn may be due to interactions between water, agricultural soil and agricultural practices. Trace elements such as $\mathrm{B}, \mathrm{Cd}, \mathrm{Cr}, \mathrm{Cu}, \mathrm{Ni}, \mathrm{Pb}$ and $\mathrm{Zn}$ are included in a different cluster, which reflects anthropogenic activities and rapidly developing industry sectors that are close to the Rosetta Branch. We also affirm that the main reasons for contamination of surface water by trace elements are leaching and precipitation with increasing human activities [80,81]. Therefore, we state that the main causes for trace elements surface water contamination in the northern Nile Delta are industrial leaching and runoff with increasing human activities.

\subsection{Water Quality Assessment for Irrigation}

\subsubsection{Irrigation Water Quality (IWQ)}

The surface water suitability for irrigation purposes is calculated (Table 3), according to the cumulative effect of the five hazard groups [36]. The computed IWQ values across two years varied from 36.3 to 37.6, with a mean value of 36.9 (Table 4) and the classification of IWQ suitability showed that the majority of surface water samples $(82 \%)$ are in a high class and $18 \%$ of samples are in a medium class (Table 5). The water suitability for irrigation based on physicochemical parameters of water are shown in the overall index map; this map can be used to estimate the validation of surface water used for irrigation. The final map is acceptable for use in prospective agricultural management plans and to evaluate the overall efficiency of surface water to determine surface water suitability for irrigation. The IWQ distribution maps over two years (Figures 5 and 6) reflect deterioration in the water quality in the northern and west regions of the study area near the Rosetta Branch, due to geogenic sources and excessive anthropogenic activities. Therefore, there are many factors that deteriorate the condition of irrigation water, including the unregulated drainage of waste from residential areas in the sample region [7,82]. Several indices measured can also help determine the validation of irrigation water and are addressed in the following sections. 
Table 3. Classification of IWQ for surface water samples.

\begin{tabular}{|c|c|c|c|c|c|c|c|}
\hline \multirow[b]{2}{*}{ Hazard Group } & \multirow[b]{2}{*}{ Weight } & \multirow[b]{2}{*}{ Parameter } & \multirow[b]{2}{*}{ Range } & \multirow[b]{2}{*}{ Rating } & \multirow[b]{2}{*}{ Suitability } & \multicolumn{2}{|c|}{ Samples (\%) } \\
\hline & & & & & & First Year & Second Year \\
\hline \multirow{3}{*}{ Salinity hazard } & \multirow{3}{*}{5} & \multirow{3}{*}{$\begin{array}{c}\text { Electrical } \\
\text { conductivity }(\mu \mathrm{S} / \mathrm{cm})\end{array}$} & $\mathrm{EC}<700$ & 3 & High & $93 \%$ & $71 \%$ \\
\hline & & & $700 \leq \mathrm{EC} \leq 3000$ & 2 & Medium & $7 \%$ & $29 \%$ \\
\hline & & & $\mathrm{EC}>3000$ & 1 & Low & Nil & Nil \\
\hline \multirow{3}{*}{$\begin{array}{l}\text { Infiltration and } \\
\text { permeability } \\
\text { hazard }\end{array}$} & \multirow{3}{*}{4} & \multirow{3}{*}{$\begin{array}{l}\text { Electrical conductivity } \\
(\mu \mathrm{S} / \mathrm{cm}) \text { with Sodium } \\
\text { Adsorption Ratio }\end{array}$} & \multirow{3}{*}{$\begin{array}{l}\text { (See Table S3 } \\
\text { for details) }\end{array}$} & 3 & High & $93 \%$ & $71 \%$ \\
\hline & & & & 2 & Medium & $7 \%$ & $29 \%$ \\
\hline & & & & 1 & Low & Nil & Nil \\
\hline \multirow{6}{*}{$\begin{array}{l}\text { Specific ion } \\
\text { toxicity }\end{array}$} & \multirow{6}{*}{3} & \multirow{3}{*}{$\begin{array}{c}\text { Sodium Absorption } \\
\text { Ratio (-) }\end{array}$} & SAR $<3.0$ & 3 & High & $100 \%$ & $100 \%$ \\
\hline & & & $3.0 \leq \mathrm{SAR} \leq 9.0$ & 2 & Medium & Nil & Nil \\
\hline & & & $\mathrm{SAR}>9.0$ & 1 & Low & Nil & Nil \\
\hline & & \multirow{3}{*}{ Chloride (mg/L) } & $\mathrm{Cl}^{-}<140$ & 3 & High & $100 \%$ & $100 \%$ \\
\hline & & & $140 \leq \mathrm{Cl}^{-} \leq 350$ & 2 & Medium & Nil & Nil \\
\hline & & & $\mathrm{Cl}^{-}>350$ & 1 & Low & Nil & Nil \\
\hline \multirow{3}{*}{$\begin{array}{l}\text { Trace element } \\
\text { toxicity }\end{array}$} & \multirow{3}{*}{2} & \multirow{3}{*}{$\begin{array}{l}\mathrm{B}, \mathrm{Cd}, \mathrm{Cr}, \mathrm{Cu}, \mathrm{Fe}, \mathrm{Mn}, \\
\mathrm{Ni}, \mathrm{Pb} \text { and } \mathrm{Zn}(\mathrm{mg} / \mathrm{L})\end{array}$} & \multirow{3}{*}{$\begin{array}{l}\text { (See Table S4 } \\
\text { for details) }\end{array}$} & 3 & High & $100 \%$ & $100 \%$ \\
\hline & & & & 2 & Medium & Nil & Nil \\
\hline & & & & 1 & Low & Nil & Nil \\
\hline \multirow{9}{*}{$\begin{array}{l}\text { Miscellaneous } \\
\text { effects to } \\
\text { sensitive crops }\end{array}$} & \multirow{9}{*}{1} & \multirow{3}{*}{$\begin{array}{l}\text { Nitrate Nitrogen } \\
(\mathrm{mg} / \mathrm{L})\end{array}$} & $\mathrm{NO}_{3}{ }^{-}<5.0$ & 3 & High & $100 \%$ & $100 \%$ \\
\hline & & & $5.0 \leq \mathrm{NO}_{3}{ }^{-} \leq 30.0$ & 2 & Medium & Nil & Nil \\
\hline & & & $\mathrm{NO}_{3}{ }^{-}>30.0$ & 1 & Low & Nil & Nil \\
\hline & & \multirow{3}{*}{ Alkalinity (mg/L) } & Alkalinity $<90$ & 3 & High & Nil & Nil \\
\hline & & & $90 \leq$ alkalinity $\leq 500$ & 2 & Medium & $100 \%$ & $100 \%$ \\
\hline & & & Alkalinity $>500$ & 1 & Low & Nil & Nil \\
\hline & & \multirow{3}{*}{$\mathrm{pH}$} & $7.0 \leq \mathrm{pH} \leq 8.0$ & 3 & High & $75 \%$ & $62 \%$ \\
\hline & & & $\begin{array}{c}6.5 \leq \mathrm{pH}<7.0 \text { and } \\
8.0<\mathrm{pH} \leq 8.5\end{array}$ & 2 & Medium & $25 \%$ & $33 \%$ \\
\hline & & & $\mathrm{pH}<6.5$ or $\mathrm{pH}>8.5$ & 1 & Low & Nil & $4 \%$ \\
\hline
\end{tabular}

Table 4. Statistical description of the six Water Quality Indices (WQIs) in the northern Nile Delta.

\begin{tabular}{ccccccc}
\hline IWQIs & IWQ & Na\% & SAR & PI & KI & RSC \\
\hline \multicolumn{7}{c}{ The first year $(n=55)$} \\
Minimum & 36.33 & 22.20 & 0.46 & 60.12 & 0.20 & -1.14 \\
Maximum & 37.66 & 43.20 & 1.57 & 85.58 & 0.69 & 0.64 \\
Mean & 37.34 & 31.57 & 0.99 & 71.81 & 0.41 & -0.11 \\
Standard deviation & 0.29 & 5.09 & 0.30 & 5.42 & 0.11 & 0.33 \\
\hline \multicolumn{7}{c}{ The second year $(\boldsymbol{n}=\mathbf{5 5})$} \\
Minimum & 36.00 & 22.58 & 0.53 & 58.59 & 0.22 & -1.47 \\
Maximum & 37.66 & 42.14 & 1.70 & 80.77 & 0.65 & 0.40 \\
Mean & 37.16 & 31.75 & 1.07 & 67.52 & 0.41 & -0.35 \\
Standard deviation & 0.46 & 4.48 & 0.29 & 4.99 & 0.09 & 0.39 \\
\hline & Data across two years $(n=\mathbf{1 1 0})$ & & \\
Minimum & 36.33 & 22.20 & 0.46 & 58.59 & 0.20 & -1.47 \\
Maximum & 37.66 & 43.20 & 1.70 & 85.58 & 0.69 & 0.64 \\
Mean & 37.26 & 31.67 & 1.04 & 69.67 & 0.41 & -0.23 \\
Standard deviation & 0.30 & 5.10 & 0.30 & 5.42 & 0.11 & 0.33 \\
\hline
\end{tabular}

Table 5. Classification of surface water quality according to WQIs.

\begin{tabular}{ccccc}
\hline \multirow{2}{*}{ Water Quality Indices } & \multirow{2}{*}{ Range } & Water Class & \multicolumn{2}{c}{ Samples (\%) } \\
\cline { 3 - 5 } & & & First Year & Second Year \\
\hline \multirow{3}{*}{ Irrigation Water Quality (IWQ) } & 222 & Low & Nil & Nil \\
& $>37$ & Medium & $11 \%(6$ samples $)$ & $25 \%$ (14 samples) \\
& $>37$ & High & $89 \%$ (49 samples) & $75 \%$ (41 samples) \\
\hline
\end{tabular}


Table 5. Cont

\begin{tabular}{|c|c|c|c|c|}
\hline \multirow{2}{*}{ Water Quality Indices } & \multirow{2}{*}{ Range } & \multirow{2}{*}{ Water Class } & \multicolumn{2}{|c|}{ Samples (\%) } \\
\hline & & & First Year & Second Year \\
\hline \multirow{5}{*}{ Sodium Percentage (Na\%) } & $<20$ & Excellent & Nil & Nil \\
\hline & $20-40$ & Good & 96\% (53 samples) & $96 \%$ (53 samples) \\
\hline & $40-60$ & Permissible & 4\% (2 samples) & $4 \%$ (2 samples) \\
\hline & $60-80$ & Doubtful & Nil & Nil \\
\hline & $>80$ & Unsuitable & Nil & Nil \\
\hline \multirow{4}{*}{ Sodium Absorption Ratio (SAR) } & $<10$ & Excellent & $100 \%$ (55 samples) & $100 \%$ (55 samples) \\
\hline & $10-18$ & Good/safe & Nil & Nil \\
\hline & $18-26$ & Doubtful/moderate & Nil & Nil \\
\hline & $>26$ & Unsuitable & Nil & Nil \\
\hline \multirow{3}{*}{ Permeability Index (PI) } & $>75 \%$ & Good-Class I & 29\% (16 samples) & $9 \%$ (5 samples) \\
\hline & $25 \%-75 \%$ & Good-Class II & 71\% (39 samples) & $91 \%$ (50 samples) \\
\hline & $<25 \%$ & Unsuitable-Class III & Nil & Nil \\
\hline \multirow{2}{*}{ Kelley Index (KI) } & $<1$ & Good & 100\% (55 samples) & $100 \%$ (55 samples) \\
\hline & $>1$ & Unsuitable & Nil & Nil \\
\hline \multirow{3}{*}{$\begin{array}{l}\text { Residual Sodium Carbonate } \\
\text { (RSC) }\end{array}$} & $<1.25$ & Good & 100\% (55 samples) & $100 \%$ (55 samples) \\
\hline & $1.25-2.5$ & Doubtful & Nil & Nil \\
\hline & $>2.5$ & Unsuitable & Nil & Nil \\
\hline
\end{tabular}
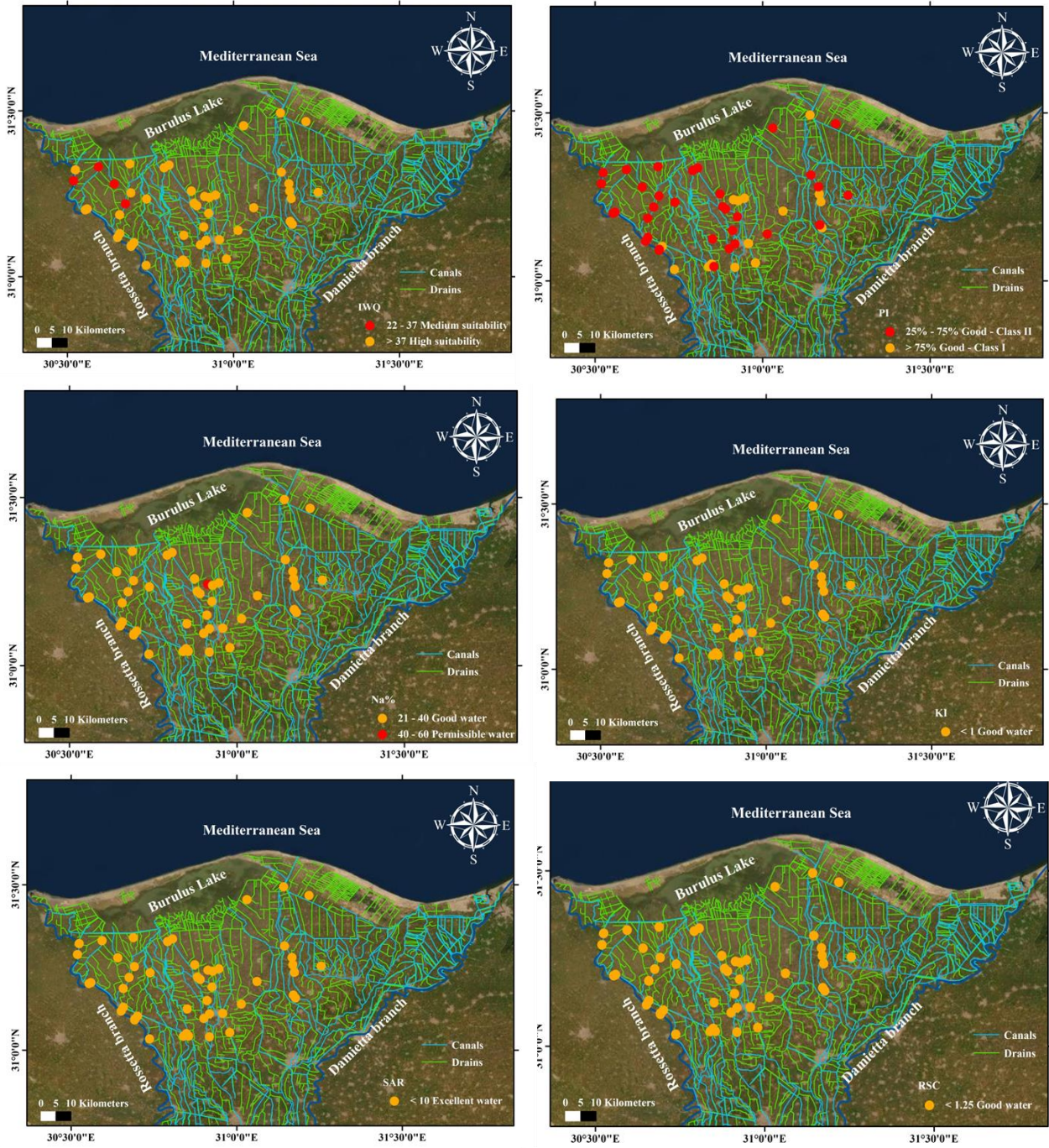

Figure 5. Spatial variation maps of Irrigation Water Quality Indices in year 2018. 

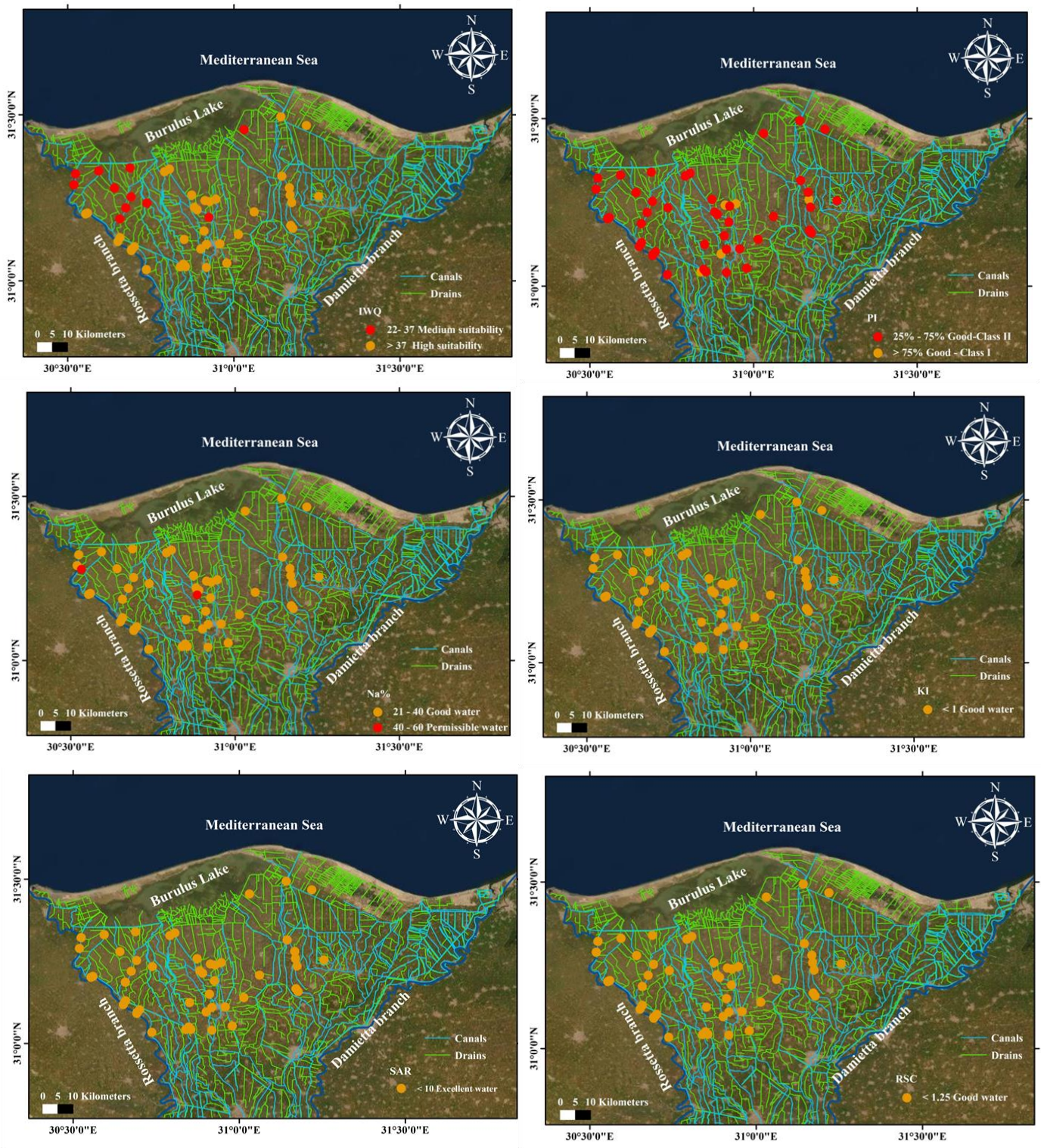

Figure 6. Spatial variation maps of Irrigation Water Quality Indices in year 2019.

\subsubsection{Sodium Percentage}

The $\mathrm{Na} \%$ is often utilized to identify the surface water suitability for agricultural application. The high contents of $\mathrm{Na}^{+}$in surface water, relative to $\mathrm{Ca}^{2+}$ and $\mathrm{Mg}^{2+}$ concentrations, react with the soil and decrease its permeability, which contributes to a deterioration of the soil structure, thus, development of stunting plant $[67,69,83-85]$. The $\mathrm{Na} \%$ values across two years ranged from 22.4 to 42.6, with a mean value of 32.5 (Table 4). According to $\mathrm{Na} \%$ values, the majority of water samples are in a good class for irrigation $(96 \%)$, while the remaining samples $(4 \%)$ fell into within a permissible suitability for irrigation (Table 5, Figures 5 and 6). The Wilcox Diagram (Figure 7) showed that the majority of the surface water samples (91\%) are good to permissible for irrigation, while $11 \%$ of the samples are excellent to good, which stated that the surface water in the investigated area is a perfect for irrigation. 


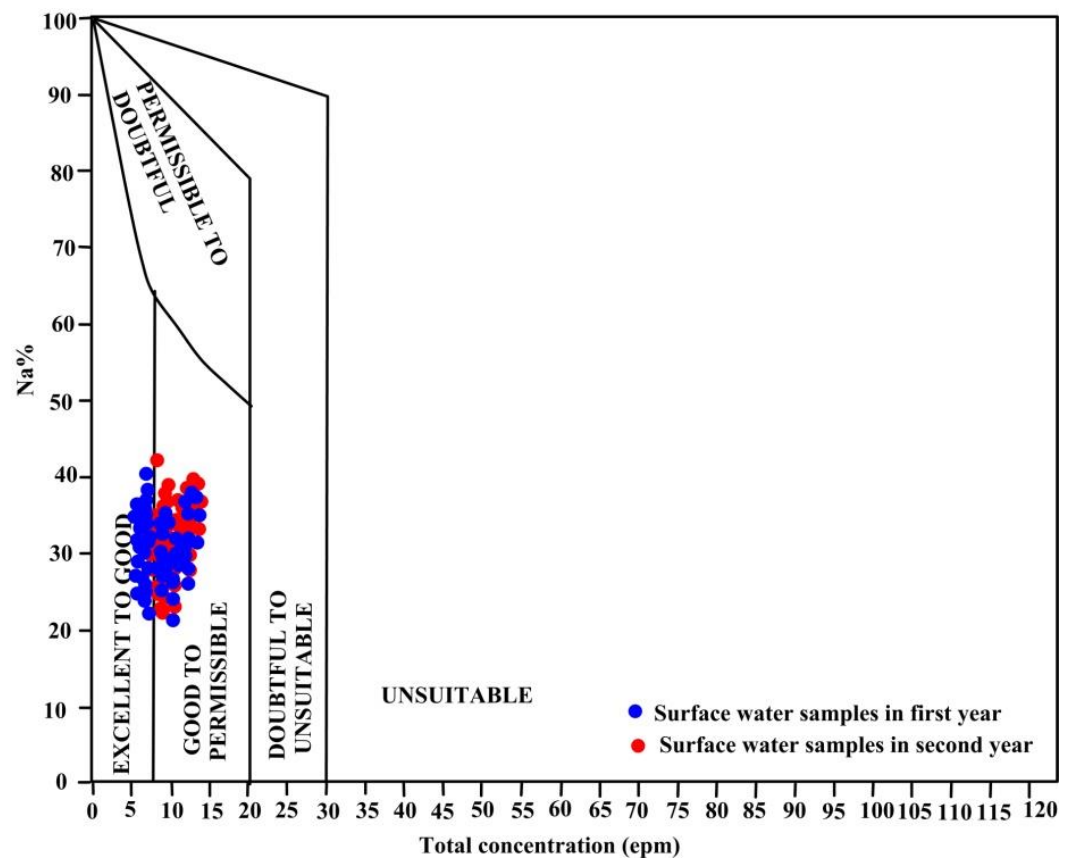

Figure 7. Wilcox Diagram to assess surface water quality for irrigation in two years.

\subsubsection{Sodium Absorption Ratio}

The SAR is a significant index for assessing the suitability of irrigated water to sodium hazard $[86,87]$ and It relates more closely to the soil's exchangeable sodium percentages [88]. The SAR values across two years varied from 0.51 to 1.61 with a mean value of 1.06 (Table 4), all surface water samples are excellent for irrigation (SAR < 10) according to the SAR classification (Table 5). SAR calculates the relative proportion of $\mathrm{Na}^{+}$to $\mathrm{Ca}^{2+}$ and $\mathrm{Mg}^{2+}$ ions in a water sample, so that the high contents of $\mathrm{Ca}^{2+}$ and $\mathrm{Mg}^{2+}$ in irrigation water reduces the soil permeability [89-92]. Suarez et al. [88] found that the hydraulic conductivity and aggregate stability decrease as the elevated SAR values decrease, in addition to affecting the clay dispersion, expandable clay swelling, surface crusting, and reduced tillage. The SAR value represents the sodium hazard and is calculated using the formula (Table 1) given by Wilcox [22] and Hem [93]. The SAR value is plotted against the EC to rate irrigation waters [21]. The plot revealed that most surface water samples fell into the C2-S1 category and a few samples fell into the C3-S1 category, which shows that the surface waters in the investigated area have a medium salinity and low sodium content (Figure 8). According to US Salinity Laboratory [21] classification, the surface waters in the study area are within a low salinity field $(<2250 \mu \mathrm{S} / \mathrm{cm})$; thus, the water is highly appropriate for irrigation.

\subsubsection{Permeability Index}

The PI is often utilized to assess the appropriateness of the irrigation water, which is influenced by the long-term exposure of irrigation water with a high content of $\mathrm{Na}^{+}, \mathrm{Ca}^{2+}, \mathrm{Mg}^{2+}$ and alkalinity ions [94]. According to the PI values across two years, the surface water samples were classified into two classes, good-class II, which represent $81 \%$ of samples and good-class I, which represents $19 \%$ of the samples (Figures 5 and 6); therefore, the surface water qualities were validated for irrigation. 



Figure 8. The United States Salinity Laboratory USSL Diagram to assess surface water quality for irrigation in two years.

\subsubsection{Kelley Index}

The KI also assessed the suitability of the water used for irrigation. The KI revealed an excess in the quantity of sodium in water [95]. The KI values across two years varied from 0.21 to 0.67 , with a mean value of 0.44 , and based on the KI results, all surface water samples $(100 \%)$ fell into the good class and are acceptable for irrigation (Table 5, Figures 5 and 6). The KI values lower than one $(\mathrm{KI}<1)$ are suitable for irrigation, whereas a value bigger than one $(\mathrm{KI}>1)$ illustrate that excess sodium in the water was found $[70,85]$.

\subsubsection{Residual Sodium Carbonate}

The alkalinity content plays an important role in determining the water suitability for irrigation water. The alkalinity concentration in excess of alkaline earth metals $\left(\mathrm{Ca}^{2+}\right.$ and $\left.\mathrm{Mg}^{2+}\right)$ generates the term 'Residual Sodium Carbonate' (RSC) [85,94], which indicates the hazardous effect of alkalinity on water quality for irrigation. The RSC values across two years varied from -1.27 to 0.52 with a mean value of -0.37 and according to the RSC results, all surface water samples fell into a good class $(100 \%)$ and are acceptable for irrigation, where the RSC values are less than 1.25 (Table 5, Figures 5 and 6). The suitability of surface water depends on the results of the excess alkalinity more than it does on the sum of the $\mathrm{Ca}^{2+}$ and $\mathrm{Mg}^{2+}$ concentrations in water. Water suitability depends on the abundance of the $\mathrm{Na}^{+}$content and the excess alkalinity, with respect to the alkaline earth elements. The water and air movement in the soil may be stopped by covering the pores of the soil with the salt produced by continuous usage of RSC above 2.5 meq/L [95].

\subsection{Correlation Coefficient of the Relationship between WQIs with Respect to the Physicochemical Parameters}

The Pearson's correlation coefficient was used to estimate the relationship among the major ions and six WQIs for irrigation and to detect significance levels of 0.05 and 0.001 , as shown in Figure 9. The significant correlation coefficients for the matrix of the major ions and six WQIs varied from 0.28 to 0.99 . The correlations among the major ions and six WQIs indicated that $\mathrm{NO}_{3}{ }^{-}$showed a 
non-significant correlation with the six WQIs and the rest of the major ions. The TDS and $\mathrm{Ca}^{2+}$ values showed the highest and most significant correlation with IWQ, with $r$-values of 0.76 and 0.70 , respectively. However, these values showed a low and non-significant correlation with RSC. The TDS, $\mathrm{Ca}^{2+}$ and alkalinity values showed moderate to high correlations with all WQIs expect with RSC, with $r$-values ranging from 0.38 to 0.80 . The $\mathrm{Cl}^{-}$and $\mathrm{SO}_{4}{ }^{2-}$ showed moderate to high correlations with all WQIs, with $r$-values ranging from 0.36 to $0.70 . \mathrm{Mg}^{2+}$ values showed significant and high correlations with IWQ and PI and a moderate correlation with RSC. In cation $\left(\mathrm{Ca}^{2+}\right)$ and in anion (alkalinity), the values showed a high and significant correlation with TDS, with $r$-values ranging between 0.93 and 0.91 , and with IWQ, with $r$-values between 0.70 and 0.65 , respectively. The correlation analysis between the two variables presents a perfect linear relationship [80]; therefore, the correlation metric with TDS and IWQ revealed that $\mathrm{Ca}^{2+}$ was the most affected cation and alkalinity was the most affected anion. These results are in agreement with the water facies, which were presented by the Piper Diagram and reflected the effects of weathering and rock water interactions reported in the Gibbs Diagram [71]. In general, there were weak relationships between the trace elements and six WQIs of surface water.

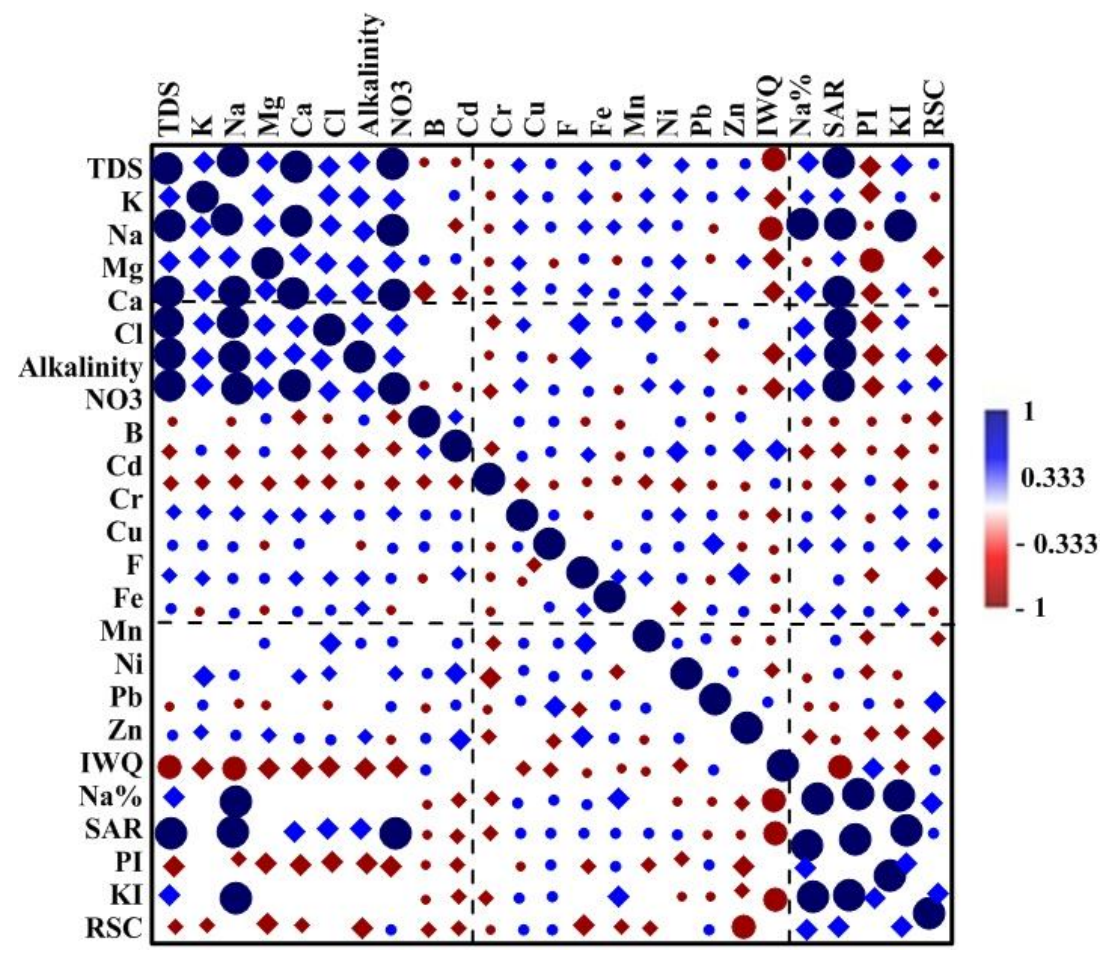

Figure 9. Correlation matrix for chemical elements and WQIs for irrigation across two years.

\subsection{Multivariate Statistical Analysis}

3.6.1. Using Principal Component Regression and Support Vector Machine Regression to Predict WQIs for Irrigation

Accurate estimations of the six WQIs of the water samples can be calculated by the mathematical methods listed in Table 1 [66-70]. In this study, PCR was tested as alternative approaches to predict Water Quality Indices (WQIs). The PCR and SVMR predict a single model based on multiple response variables $[51,96,97]$. The two models were used to assess the WQIs as output data depending on the major ions and trace elements as input data for IWQ and based on several major ions as input data for the other five indices (Table 1). Figures 10 and 11 present the relationships of six WQIs between the observed and predicted values in a 1:1 scatter plot using both PCR and SVMR, respectively for the Val. models. Both models of the PCR and SVMR provided accurate predictions of six WQIs in the models 
of Cal. and Val. For example, the PCR models of six IWQs had $R^{2}$ values varying from 0.85 to 0.98 in the Cal. (Table 6) and varying from 0.60 to 0.99 in the Val. datasets (Figure 10), and with slopes varying from 0.85 to 0.98 in the Cal. and varying from 0.80 to 1.10 in the Val. dataset. For example, The RMSE values for $\mathrm{Na} \%$ were 1.470 in the Cal. dataset and 1.720 in the Val. dataset and the PI values were 2.956 for the Cal. dataset and 2.191 for the Val. dataset. The PCs was selected to support the calibration data without over-fitting the PCR models and it varied from 3 to 6 for the six WQIs (Figure 10).
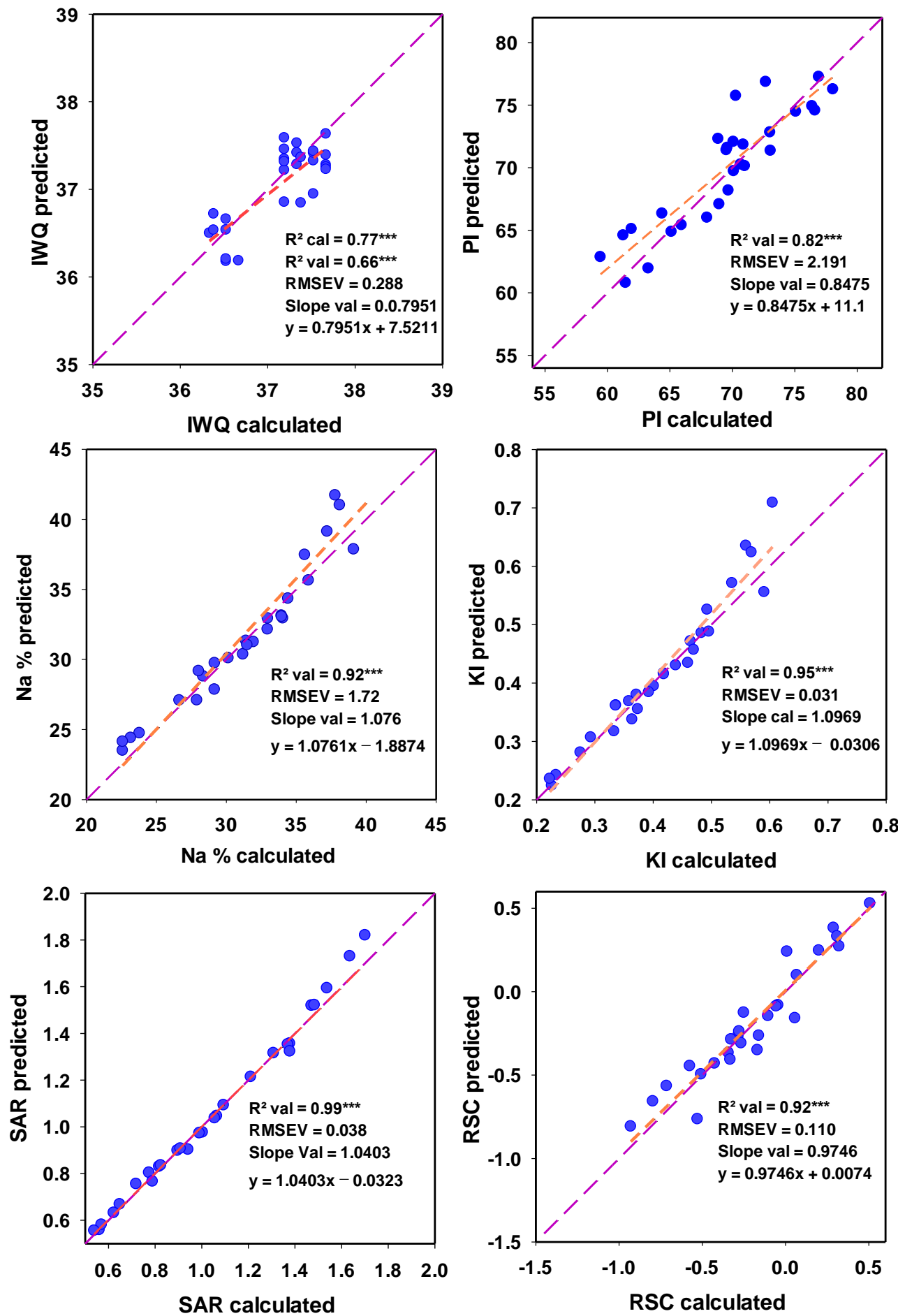

Figure 10. The validation models of relationships between observed against predicted for the six Water Quality Indices (WQIs) based on the Principal Component Regression (PCR). 

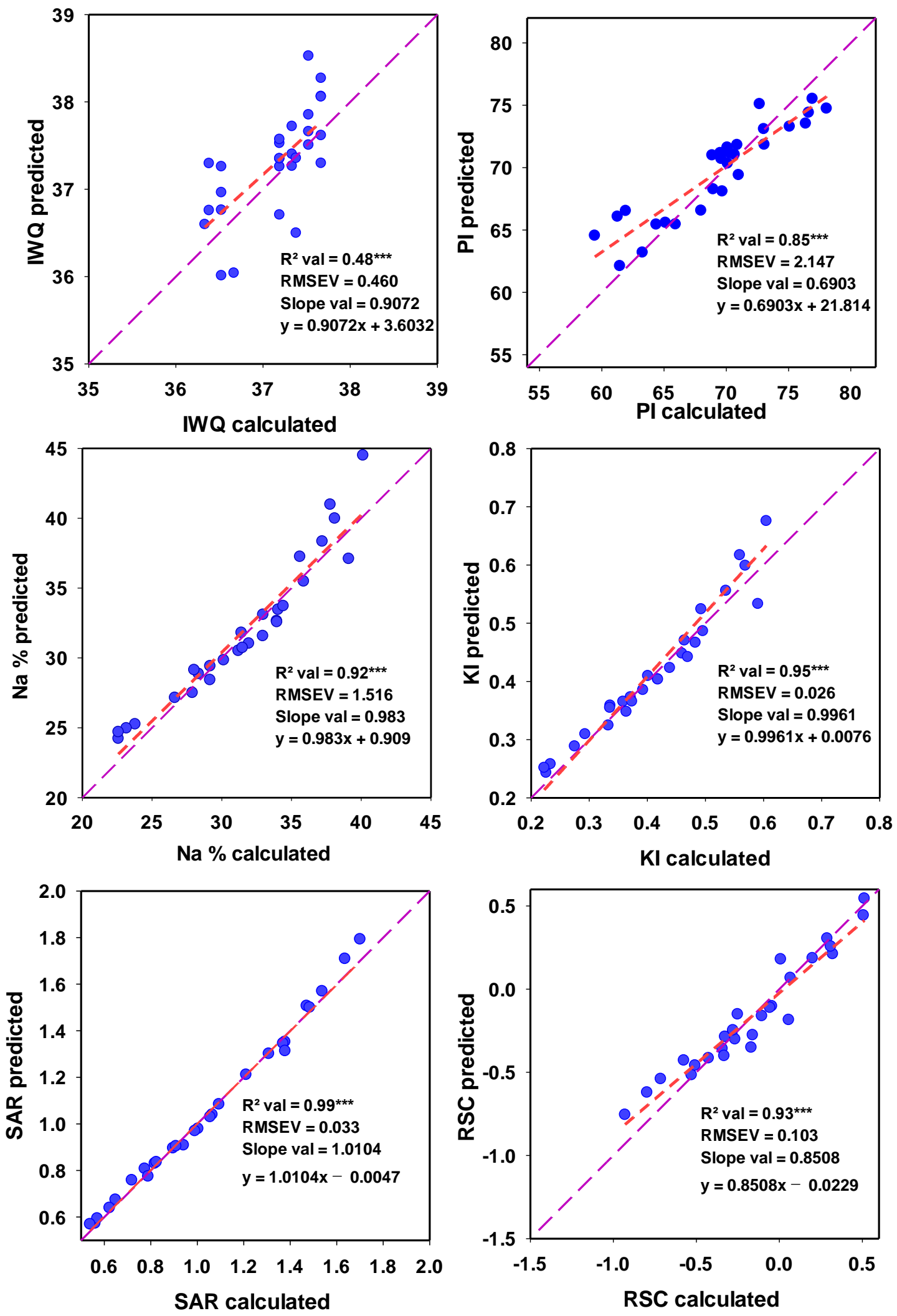

Figure 11. The validation models of relationships between observed against predicted for the six Water Quality Indices (WQIs) based on the Support Vector Machine Regression (SVMR).

The SVMR models of six IWQs had $R^{2}$ values varying from 0.88 to 0.98 in the Cal. (Table 6) and varying from 0.48 to 0.99 in the Val. datasets (Figure 11), and with slopes varying from 0.77 to 1.04 in 
the Cal. and varying from 0.80 to 1.10 in the Val. dataset. For example, the RMSE values for Na\% were 1.581 in the Cal. dataset and 1.516 in the Val. dataset and the PI values were 2.325 for the Cal. dataset and 2.14 for the Val. dataset.

In the same line of this study to predict Water Quality Indices with another multivariate modelling, Gad et al. [71] found that the Partial Least Squares Regression (PLSR) could be used to assess the Drinking Water Quality Index (DWQI) and the three water pollution indices such as Contamination Index (CD), Trace Element Evaluation Index (HEI) and Trace Element Pollution Index (HPI) of surface water. Wang et al. [98] found that hybrid wavelet-based support vector regression Structure (WA-PSO-SVR) based on wavelet analysis (WA) could be used to estimate ammonia nitrogen $\left(\mathrm{NH}_{3}-\mathrm{N}\right)$ and chemical oxygen demand and in the Grand Canal from Beijing to Hangzhou. In general, the PCR and SVMR models provided robust and reliable estimates of the different indices and showed the highest $R^{2}$ and the highest slopes values near to 1.00, as well as minim values of RMSE in both models.

Table 6. Coefficient of determination $\left(R^{2}\right)$, root mean squared error (RMSE), and slope and equations for calibration $\left(R^{2}\right.$ cal,$R_{\text {MSE }}$, slope cal $_{\text {and }}$ Equation $\left.{ }_{\text {cal }}\right)$ statistics of the PCR and SVMR models for the (IWQIs). ${ }^{* * *}: p<0.001$.

\begin{tabular}{|c|c|c|c|c|c|}
\hline \multirow{2}{*}{ IWQIs } & \multirow{2}{*}{ PCs } & \multicolumn{4}{|c|}{ Calibration Dataset Based on PCR } \\
\hline & & $R_{\text {cal }}^{2}$ & RMSE $_{\text {Cal }}$ & Equation $_{\text {cal }}$ & Slope $_{\text {cal }}$ \\
\hline IWQ & 6 & $0.85^{* * *}$ & 0.178 & $y=0.8529 x+5.4691$ & 0.8529 \\
\hline $\mathrm{Na} \%$ & 4 & $0.90^{* * *}$ & 1.470 & $y=0.9016 x+3.1012$ & 0.9016 \\
\hline SAR & 3 & $0.98^{* * *}$ & 0.037 & $y=0.9828 x+0.0176$ & 0.9828 \\
\hline PI & 4 & $0.88^{* * *}$ & 2.956 & $y=0.8836 x+8.1029$ & 0.8836 \\
\hline KI & 3 & $0.91^{* * *}$ & 0.031 & $y=0.905 x+0.0391$ & 0.905 \\
\hline RSC & 3 & $0.93^{* * *}$ & 0.097 & $y=0.9323 x-0.0172$ & 0.9323 \\
\hline \multirow{2}{*}{\multicolumn{2}{|c|}{ IWQIs }} & \multicolumn{3}{|c|}{ Calibration Dataset Based on SVMR } & \\
\hline & & $R_{\text {cal }}^{2}$ & RMSE $_{\text {Cal }}$ & Equation $_{\text {cal }}$ & Slope $_{\text {cal }}$ \\
\hline \multicolumn{2}{|c|}{ IWQ } & $0.93^{* * *}$ & 0.299 & $y=1.0371 x-1.4053$ & 1.0371 \\
\hline \multicolumn{2}{|c|}{$\mathrm{Na} \%$} & $0.90^{* * *}$ & 1.581 & $y=0.808 x+5.9624$ & 0.8080 \\
\hline \multicolumn{2}{|c|}{ SAR } & $0.98^{* * *}$ & 0.038 & $y=0.9545 x+0.0437$ & 0.9545 \\
\hline \multicolumn{2}{|c|}{ PI } & $0.88^{* * *}$ & 2.325 & $y=0.7728 x+15.705$ & 0.7728 \\
\hline \multicolumn{2}{|c|}{ KI } & $0.90^{* * *}$ & 0.034 & $y=0.8062 x+0.0768$ & 0.8062 \\
\hline \multicolumn{2}{|c|}{ RSC } & $0.93^{* * *}$ & 0.119 & $y=0.8306 x-0.0493$ & 0.8306 \\
\hline
\end{tabular}

\subsubsection{Using Stepwise Multiple Linear Regressions to Predict WQIs for Irrigation}

SMLR was also tested to predict the six WQIs, and the models preformed a robust and reliable estimation for all WQIs, based on TDS and $\mathrm{Ca}^{2+}$ for IWQ, and based on several major ions for $\mathrm{Na} \%$, SAR, PI, KI and RSC, as indicated in Table 2, with $R^{2}$ values of $0.77,0.90,0.98,0.88,0.90$ and 0.93 for Cal. models and with $R^{2}$ values of $0.66,0.93,0.99,0.86,0.95$ and 0.91 for Val. for IWQ, Na\%, SAR, PI, KI and RSC, respectively (Table 7). SMLR estimates of the WQIs showed that the values of $R^{2}$ increased as the input variables from the major ions increased and the RMSE decreased as the input variables from the major ions increased. For example, the SMLR model (1) of $\mathrm{Na} \%$, based on $\mathrm{Na}^{+}$, had an $R^{2}$ value $=0.72$ and a RMSE value $=2.68$ for Val., while the SMLR model (4), based on $\mathrm{Na}^{+}, \mathrm{Mg}^{2+}$, $\mathrm{Ca}^{2+}$ and $\mathrm{K}^{+}$, had an $R^{2}$ value $=0.93$ and a $\mathrm{RMSE}$ value $=1.70$ (Table 7). Ahmed et al. [96] found that supervised machine learning that included multiple linear regression could be utilized to estimate the Water Quality Index of surface waters based on four parameters, the temperature, turbidity, $\mathrm{pH}$ and total dissolved solids, with an $R^{2}$ value $=0.66$. In our study, SMLR was used to predict the Irrigation Water Quality based on TDS and four major ions ( $\mathrm{Cr}, \mathrm{Zn}, \mathrm{Mg}^{2+}$ and $\mathrm{Cu}$ ) with an $R^{2}$ value $=0.83$ and a standard error $=0.20$. Chen and Liu [97] found that multiple linear regression models based on several physicochemical parameters could be utilized to estimate water quality variables such as dissolved oxygen, total phosphorus and chlorophyll disk depth with $R^{2}$ values of $0.64,31$, and 0.55 . 
Gad et al. [71] reported that the SMLR could be used to assess the DWQI, CD, HEI and HPI of surface water in North River Nile. The SMLR results showed that the TDS or $\mathrm{Ca}^{2+}$ was the most influential parameter, which explains why it showed the most variation in the IWQ. However, $\mathrm{Na}^{+}$was the most influential parameter in explaining $\mathrm{Na} \%$, SAR and $\mathrm{KI}$, while $\mathrm{Mg}^{2+}$ was the most influential parameter for explaining PI and RSC.

Table 7. Extraction the most influential physiochemical parameter to predict WQIs using the Stepwise Multiple Linear Regression.

\begin{tabular}{|c|c|c|c|c|c|}
\hline \multirow{2}{*}{ Model No. } & \multicolumn{2}{|l|}{ Calibration Models } & \multicolumn{3}{|c|}{ Validation Models } \\
\hline & Calibration Equations & $R_{\mathrm{cal}}^{2}$ & $R_{\text {val }}^{2}$ & RMSE $_{\text {val }}$ & Slope $_{\text {val }}$ \\
\hline \multicolumn{6}{|c|}{ IWQ } \\
\hline 1 & $\mathrm{IWQ}=38.919-0.005 \times(\mathrm{TDS})$ & $0.71 * * *$ & $0.66 * * *$ & 0.29 & 0.85 \\
\hline 2 & $\mathrm{IWQ}=38.697-0.007 \times(\mathrm{TDS})+0.026 \times\left(\mathrm{Ca}^{2+}\right)$ & $0.77^{* * *}$ & $0.66^{* * *}$ & 0.26 & 0.62 \\
\hline \multicolumn{6}{|c|}{$\mathrm{Na} \%$} \\
\hline 1 & $\mathrm{Na} \%=23.023+0.286 \times\left(\mathrm{Na}^{+}\right)$ & $0.43 * *$ & $0.72 * * *$ & 2.68 & 0.74 \\
\hline 2 & $\mathrm{Na} \%=23.66+0.361 \times\left(\mathrm{Na}^{+}\right)-0.107 \times\left(\mathrm{Mg}^{2+}\right)$ & $0.51 * *$ & $0.79 * * *$ & 2.30 & 0.74 \\
\hline 3 & \multirow{2}{*}{$\begin{array}{c}\mathrm{Na} \%=32.339+0.722 \times\left(\mathrm{Na}^{+}\right)-0.423 \times\left(\mathrm{Mg}^{2+}\right)-0.43 \times\left(\mathrm{Ca}^{2+}\right) \\
\mathrm{Na} \%=31.391+0.718 \times\left(\mathrm{Na}^{+}\right)-0.452 \times\left(\mathrm{Mg}^{2+}\right)-0.452 \times\left(\mathrm{Ca}^{2+}\right)+ \\
0.361 \times\left(\mathrm{K}^{+}\right)\end{array}$} & $0.88^{* * *}$ & $0.92 * * *$ & 1.71 & 0.79 \\
\hline 4 & & $0.90^{* * *}$ & $0.93^{* * *}$ & 1.70 & 1.08 \\
\hline \multicolumn{6}{|c|}{ SAR } \\
\hline 1 & $\mathrm{SAR}=0.285+0.025 \times\left(\mathrm{Na}^{+}\right)$ & $0.90 * * *$ & $0.95^{* * *}$ & 0.07 & 0.93 \\
\hline 2 & $\mathrm{SAR}=0.303+0.027 \times\left(\mathrm{Na}^{+}\right)-0.003 \times\left(\mathrm{Mg}^{2+}\right)$ & $0.91 * *$ & $0.97 * * *$ & 0.06 & 0.93 \\
\hline 3 & SAR $=0.528+0.036 \times\left(\mathrm{Na}^{+}\right)-0.011 \times\left(\mathrm{Mg}^{2+}\right)-0.011 \times\left(\mathrm{Ca}^{2+}\right)$ & $0.98^{* * *}$ & $0.99^{* * *}$ & 0.04 & 1.04 \\
\hline \multicolumn{6}{|c|}{ PI } \\
\hline 1 & $\mathrm{PI}=75.56-0.223 \times\left(\mathrm{Mg}^{2+}\right)$ & $0.32 * *$ & $0.27^{* *}$ & 4.34 & 0.37 \\
\hline 2 & $\mathrm{PI}=85.973-0.341 \times\left(\mathrm{Mg}^{2+}\right)-0.285 \times\left(\mathrm{Ca}^{2+}\right)$ & $0.57 * * *$ & 0.27 * & 4.57 & 0.45 \\
\hline 3 & $\mathrm{PI}=88.652-0.656 \times\left(\mathrm{Mg}^{2+}\right)-0.61 \times\left(\mathrm{Ca}^{2+}\right)+0.427 \times\left(\mathrm{Na}^{+}\right)$ & $0.82 * * *$ & $0.62 * * *$ & 3.15 & 0.77 \\
\hline 4 & $\begin{array}{c}\mathrm{PI}=86.711-0.822 \times\left(\mathrm{Mg}^{2+}\right)-0.802 \times\left(\mathrm{Ca}^{2+}\right)+0.419 \times\left(\mathrm{Na}^{+}\right)+ \\
0.074 \times(\text { Alkalinity })\end{array}$ & $0.88^{* * *}$ & $0.86^{* * *}$ & 2.38 & 0.79 \\
\hline \multicolumn{6}{|c|}{ KI } \\
\hline 1 & $\mathrm{KI}=0.226+0.006 \times\left(\mathrm{Na}^{+}\right)$ & $0.44^{* *}$ & $0.73^{* * *}$ & 0.06 & 0.62 \\
\hline 2 & $\mathrm{KI}=0.241+0.008 \times\left(\mathrm{Na}^{+}\right)-0.002 \times\left(\mathrm{Mg}^{2+}\right)$ & $0.53 * * *$ & $0.82 * * *$ & 0.05 & 0.75 \\
\hline 3 & $\mathrm{KI}=0.426+0.016 \times\left(\mathrm{Na}^{+}\right)-0.009 \times\left(\mathrm{Mg}^{2+}\right)-0.009 \times\left(\mathrm{Ca}^{2+}\right)$ & $0.90^{* * *}$ & $0.95^{* * *}$ & 0.04 & 1.14 \\
\hline \multicolumn{6}{|c|}{ RSC } \\
\hline 1 & $\mathrm{RSC}=0.023-0.011 \times\left(\mathrm{Mg}^{2+}\right)$ & 0.16 & 0.03 & 0.40 & 0.08 \\
\hline 2 & RSC $=-0.42-0.015 \times\left(\mathrm{Mg}^{2+}\right)+0.003 \times($ Alkalinity $)$ & $0.26 *$ & $0.30 * *$ & 0.33 & 0.28 \\
\hline 3 & $\begin{array}{c}\text { RSC }=-0.141-0.059 \times\left(\mathrm{Mg}^{2+}\right)+0.017 \times(\text { Alkalinity })- \\
0.057 \times\left(\mathrm{Ca}^{2+}\right)\end{array}$ & $0.93^{* * *}$ & $0.91 * * *$ & 0.13 & 0.99 \\
\hline
\end{tabular}

\section{Conclusions}

To comprehensively assess the surface water quality of irrigation systems and the mechanisms that control this quality, Water Quality Indices (WQIs) and multivariate models were applied to 21 physicochemical parameters of the collected surface water samples. The WQIs values showed that most of the surface water samples are ideal for irrigation. The influence of geochemical processes on the Irrigation Water Quality of the Nile River between two years has not been significant, resulting in the high self-assimilation capacity of river water. The deterioration in the quality of surface water used for irrigation in a few samples could be attributed to geogenic pollution and human activities, especially downstream of the Rosetta Branch in the north western parts. The PCR, SVMR, and SMLR models based on several chemical parameters can be used as alternative methods of assessing Water Quality Indices for irrigation. Irrigation Water Quality Indices (WQIs) and multivariate statistical analyses are effective and applicable for assessing surface water quality and controlling mechanisms. Future research should integrate the results of the models and should test them at a large scale under different environmental conditions, as well as with different physical parameters. The implementation of a prescriptive approach from the expected values will contribute to potential facilities to help 
decision and policy makers. It is hoped that these results will improve water quality management and reduce water pollution.

Supplementary Materials: The following are available online at http://www.mdpi.com/2073-4441/12/12/3300/s1. Table S1. Analytical results of the measured physicochemical parameters in the collected surface water samples during summer 2018. Table S2. Analytical results of the measured physicochemical parameters in the collected surface water samples during summer 2019. Table S3. Infiltration and permeability hazard group classification according to rate [36]. Table S4. Classification of trace element toxicity [36].

Author Contributions: Conceptualization, S.E. and M.G.; Methodology, H.H. and F.S.M.; Software, S.E., M.G., F.S.M., H.H. and K.M.K.; Formal Analysis, M.G., S.E., H.H. and F.S.M.; Resources, K.M.K.; Data Curation, H.H., M.G., F.S.M. and S.E.; Writing-Original Draft Preparation, M.G., F.S.M., S.E. and H.H.; Writing-Review \& Editing, E.M.E., S.E. and M.G.; Supervision, E.M.E.; Project Administration, E.M.E.; Funding Acquisition, K.M.K. All authors have read and agreed to the published version of the manuscript.

Funding: The authors extend their appreciation to the Deanship of Scientific Research at King Khalid University for funding this work through General Research Project under grant number 123.

Conflicts of Interest: All of the authors confirm that there are no conflict of interest.

\section{References}

1. El-Hendawy, S.; Al-Suhaibani, N.; Elsayed, S.; Hassan, W.M.; Dewir, Y.H.; Refay, Y.; Abdella, K.A. Potential of the existing and novel spectral reflectance indices for estimating the leaf water status and grain yield of spring wheat exposed to different irrigation rates. Agric. Water Manag. 2019, 217, 356-373. [CrossRef]

2. Khalifa, M.R.; Rabie, A.; Youssef, S.M.; El-Henawy, A.S. Evaluation of available sources of irrigation water at North Delta and its effect on soil salt storage under some field crops; Scientific Symposium on "Problems of Soils and Waters in Dakahlia and Damietta Governorates". Mansoura Univ. Mansoura Egypt 2003, 18, 43-52.

3. Mohamed, E.S.; Abu-Hashim, M.; Belal, A.A.A. Sustainable Indicators in Arid Region: Case Study-Egypt. In The Handbook of Environmental Chemistry; Springer Science and Business Media LLC: Berlin/Heidelberg, Germany, 2018; pp. 273-293.

4. Kawy, W.A.M.A. Using GIS modeling to assess the agricultural sustainability in Kafr El-Sheikh Governorate, Nile Delta, Egypt. Arab. J. Geosci. 2018, 6, 733-747. [CrossRef]

5. Mohamed, E.S.; Belal, A.; Shalaby, A. Impacts of soil sealing on potential agriculture in Egypt using remote sensing and GIS techniques. Eurasian Soil Sci. 2015, 48, 1159-1169. [CrossRef]

6. Aminiyan, M.M.; Aminiyan, F.M.; Heydariyan, A. Study on hydrochemical characterization and annual changes of surface water quality for agricultural and drinking purposes in semi-arid area. Sustain. Water Resour. Manag. 2016, 2, 473-487. [CrossRef]

7. El-Bouraie, M.M.; El-Barbary, A.A.; Yehia, M.M.; Motawea, E.A. Heavy metal concentrations in surface river water and bed sediments at Nile Delta in Egypt. Suo 2010, 61, 1-12.

8. Gibbs, R.J. Mechanisms controlling world water chemistry. Science 1970, 170, 10881. [CrossRef]

9. Gad, M.; El Osta, M. Geochemical controlling mechanisms and quality of the groundwater resources in El Fayoum Depression, Egypt. Arab. J. Geosci. 2020, 13, 861. [CrossRef]

10. Shakeri, A.; Ghoreyshinia, S.; Mehrabi, B. Surface and groundwater quality in Taftan geothermal field, SE Iran. Water Qual. Expo. Health 2014, 7, 205-218. [CrossRef]

11. Zhang, B.; Song, X.; Zhang, Y.; Han, D.; Tang, C.; Yu, Y.; Ma, Y. Hydrochemical characteristics and water quality assessment of surface water and groundwater in Songnen Plain, Northeast China. Water Res. 2012, 46, 2737-2748. [CrossRef]

12. Mondal, N.C.; Singh, V.P. Hydrochemical analysis of salinization for a tannery belt in Southern. India J. Hydrol. 2011, 405, 235-247. [CrossRef]

13. Sarwade, D.V.; Nandakumar, M.V.; Kesari, M.P.; Mondal, N.C.; Singh, V.S.; Singh, B. Evaluation of sea water ingress into an Indian Attoll. Environ. Geol. 2007, 52, 1475-1483. [CrossRef]

14. Saxena, V.K.; Singh, V.S.; Mondal, N.C.; Jain, S.C. Use of chemical parameters to delineation fresh ground water resources in Potharlanka Island, India. Environ. Geol. 2003, 44, 516-521. [CrossRef]

15. Zhang, W.; Ma, L.; Abuduwaili, J.; Ge, Y.; Issanova, G.; Saparov, G. Hydrochemical characteristics and irrigation suitability of surface water in the Syr Darya River, Kazakhstan. Environ. Monit. Assess. 2019, 191, 572. [CrossRef] 
16. Gad, M.; El-Hattab, M. Integration of water pollution indices and DRASTIC model for assessment of groundwater quality in El Fayoum Depression, Western Desert, Egypt. J. Afr. Earth Sci. 2019, 158, 103554. [CrossRef]

17. Jalali, M. Salinization of groundwater in arid and semiarid zones: An example from Tajarak, Western Iran. Environ. Geol. 2007, 52, 1133-1149. [CrossRef]

18. Mondal, N.C.; Singh, V.P.; Singh, V.S. Hydrochemical characteristic of coastal aquifer from Tuticorin, Tamilnadu, India. Environ. Monit. Assess. 2011, 175, 531-550. [CrossRef]

19. Singh, S.; Ghosh, N.C.; Gurjar, S.; Krishan, G.; Kumar, S.; Berwal, P. Index-based assessment of suitability of water quality for irrigation purpose under Indian conditions. Environ. Monit. Assess. 2018, 190, 29. [CrossRef]

20. Hussein, H.A.; Ricka, A.; Kuchovsky, T.; El Osta, M.M. Groundwater hydrochemistry and origin in the south-eastern part of Wadi El Natrun, Egypt. Arab. J. Geosci. 2017, 10, 170-184. [CrossRef]

21. US Salinity Laboratory (USSL). Diagnosis and Improvement of Saline and Alkaline Soils; Department of Agriculture: Washington, DC, USA, 1954.

22. Wilcox, L.V. Classification and Use of Irrigation Waters; U.S. Department of Agriculture: Washington, DC, USA, 1955.

23. Singh, G.; Rishi1, M.S.; Arora, N.K. Integrated GIS-based modelling approach for irrigation water quality suitability zonation in parts of Satluj River Basin, Bist Doab region, North India. SN Appl. Sci. 2019, 1, 1438. [CrossRef]

24. Horton, R. An Index Number System for RatingWater Quality. J. Water Pollut. Control Fed. 1965, 37, 300-306.

25. Haase, J.; Stringuini, M.; Silva, M.; Rodrigues, M.; Koch, S. Qualidade das aguas superficiais do litoral norte e médio do Rio Grande do Sul. In Proceedings of the 22 Congresso Brasileiro de Engenharia Sanitaria e Ambiental, Joinville, Brazil, 14-19 September 2003; Volume 17, pp. 1-33.

26. Arslan, B.; Akün, E. Management, contamination and quality evaluation of groundwater in North Cyprus. Agric. Water Manag. 2019, 222, 1-11. [CrossRef]

27. Kawoa, N.S.; Karuppannanb, S. Groundwater quality assessment using water quality index and GIS technique in Modjo River Basin, central Ethiopia. J. Afr. Earth Sci. 2018, 147, 300-311. [CrossRef]

28. Salem, Z.E.; Elsaiedy, G.; ElNahrawy, A. Assessment of the groundwater quality for drinking and irrigation purposes in the central Nile Delta region, Egypt. In The Handbook of Environmental Chemistry; Springer: Cham, Switzerland, 2019; Volume 73, pp. 647-684.

29. Shil, S.; Singh, U.K.; Mehta, P. Water quality assessment of a tropical river using water quality index (WQI), multivariate statistical techniques and GIS. Appl. Water Sci. 2019, 9, 168. [CrossRef]

30. Boyacioglu, H. Development of a water quality index based on a European classification scheme. Water $S A$ 2007, 33, 101-106. [CrossRef]

31. Khalil, B.; Ouarda, T.; St-Hilaire, A. Estimation of water quality characteristics at ungauged sites using artificial neural networks and canonical correlation analysis. J. Hydrol. 2011, 405, 277-287. [CrossRef]

32. Regmi, R.K.; Mishra, B.K.; Masago, Y.; Luo, P.; Toyozumi-Kojima, A.; Jalilov, S. Applying a water quality index model to assess the water quality of the major rivers in the Kathmandu Valley, Nepal. Environ. Monit. Assess. 2017, 189, 382. [CrossRef]

33. Chukwuma, C.E.; Chukwuma, C.G.; Uba, I.J.; Orakwe, C.L.; Ogbu, N.K. Irrigation water quality index assessment of Ele River in parts of Anambra State of Nigeria. Int. J. Curr. Res. 2016, 4, 1-6. [CrossRef]

34. Sener, S.; Sener, E.; Davraz, A. Evaluation of water quality using water quality index (WQI) method and GIS in Aksu River (SW-Turkey). Sci. Total Environ. 2017, 584, 131-144. [CrossRef]

35. Wang, X.; Zhang, F.; Ding, J. Evaluation of water quality based on a machine learning algorithm and water quality index for the Ebinur Lake Watershed, China. Sci. Rep. 2017, 7, 12858. [CrossRef]

36. Ayers, R.S.; Westcot, D.W. Water Quality for Agriculture: FAO Irrigation and Drainage Paper; FAO: Rome, Italy, 1985.

37. Dutta, S.; Dwivedi, A.; Kumar, M.S. Use of water quality index and multivariate statistical techniques for the assessment of spatial variations in water quality of a small river. Environ. Monit. Assess. 2018, 190, 718. [CrossRef] [PubMed]

38. Elumalai, V.; Nethononda, V.G.; Manivannan, V.; Rajmohan, N.; Li, P.; Elango, L. Groundwater quality assessment and application of multivariate statistical analysis in Luvuvhu catchment, Limpopo, South Africa. J. Afr. Earth Sci. 2020, 171, 103967. [CrossRef] 
39. Kamtchueng, B.T.; Fantong, W.Y.; Wirmvem, M.J. Hydrogeochemistry and quality of surface water and groundwater in the vicinity of Lake Monoun, West Cameroon: Approach from multivariate statistical analysis and stable isotopic characterization. Environ Monit Assess. 2016, 188, 524. [CrossRef] [PubMed]

40. Rakotondrabe, F.; Ngoupayou, J.R.; Mfonka, Z. Water quality assessment in the Betare-Oya gold mining area (East-Cameroon): Multivariate statistical analysis approach. Sci. Total Environ. 2018, 610, 831-844. [CrossRef] [PubMed]

41. Li, P.; Tian, R.; Liu, R. Solute geochemistry and multivariate analysis of water quality in the GuohuaPhosphorite Mine, Guizhou Province, China. Expo. Health 2019, 11, 81-94. [CrossRef]

42. Yidana, S.M.; Bawoyobie, P.; Sakyi, P.; Fynn, O.F. Evolutionary analysis of groundwater flow: Application of multivariate statistical analysis to hydrochemical data in the Densu Basin, Ghana. J. Afr. Earth Sci. 2018, 138, 167-176. [CrossRef]

43. Nnorom, I.C.; Ewuzie, U.; Eze, S.O. Multivariate statistical approach and water quality assessment of natural springs and other drinking water sources in Southeastern Nigeria. Heliyon 2019, 5, 01123. [CrossRef]

44. Busico, G.; Kazakis, N.; Cuoco, E.; Colombani, N.; Tedesco, D.; Voudouris, K.; Mastrocicco, M. A novel hybrid method of specific vulnerability to anthropogenic pollution using multivariate statistical and regression analyses. Water Res. 2020, 171, 115386. [CrossRef]

45. Gorai, A.K.; Hasni, S.A.; Iqbal, J. Prediction of ground water quality index to assess suitability for drinking purposes using fuzzy rule-based approach. Appl. Water Sci. 2016, 6, 393-405. [CrossRef]

46. Sahu, M.; Mahapatra, S.S.; Sahu, H.; Patel, R.K. Prediction of Water Quality Index Using Neuro Fuzzy Inference System. Water Qual. Expo. Health 2011, 3, 175-191. [CrossRef]

47. Darwishe, H.; El Khattabi, J.; Chaaban, F.; Louche, B.; Masson, E.; Carlier, E. Prediction and control of nitrate concentrations in groundwater by implementing a model based on GIS and artificial neural networks (ANN). Environ. Earth Sci. 2017, 76, 649. [CrossRef]

48. Gad, M.; El-Hendawy, S.; Al-Suhaibani, N.; Tahir, M.U.; Mubushar, M.; Elsayed, S. Combining hydrogeochemical characterization and a hyperspectral reflectance tool for assessing quality and suitability of two groundwater resources for irrigation in Egypt. Water 2020, 12, 2169. [CrossRef]

49. El Hamidi, M.J.; Larabi, A.; Faouzi, M.; Souissi, M. Spatial distribution of regionalized variables on reservoirs and groundwater resources based on geostatistical analysis using GIS: Case of Rmel-Oulad Ogbane aquifers (Larache, NW Morocco). Arab. J. Geosci. 2018, 11, 104. [CrossRef]

50. Ahmad, S.; Ghani, M.M.I. Stepwise multiple regression method to forecast fish landing. Procedia Soc. Behav. Sci. 2010, 8, 549-554.

51. Elsayed, S.; El-Gozayer, K.; Allam, A.; Schmidhalter, U. Passive reflectance sensing using regression and multivariate analysis to estimate biochemical parameters of different fruits kinds. Sci. Hortic. 2019, 243, 21-33. [CrossRef]

52. Fan, L.L.; Zhao, J.L.; Xu, X.G.; Liang, D.; Yang, G.J.; Feng, H.K.; Yang, H.; Wang, Y.; Chen, G.; Wei, P. Hyperspectral-based estimation of leaf nitrogen content in corn using optimal selection of multiple spectral variables. Sensors 2019, 19, 2898. [CrossRef]

53. Elsayed, S.; Elhewity, M.; Ibrahim, H.H.; Dewir, Y.H.; Migdadi, H.M.; Schmidhalter, U. Thermal imaging and passive reflectance sensing to estimate the water status and grain yield of wheat under different irrigation regimes. Agric. Water Manag. 2017, 189, 98-110. [CrossRef]

54. Feng, M.; Guo, X.; Wang, C.; Yang, W.; Shi, C.; Ding, G.; Zhang, X.; Xiao, L.; Zhang, M.; Song, X. Monitoring and evaluation in freeze stress of winter wheat (Triticumaestivum L.) through canopy hyper-spectrum reflectance and multiple statistical analysis. Ecol. Indic. 2018, 84, 290-297. [CrossRef]

55. Wang, J.; Liu, G.; Liu, H.; Lam, P.K. Multivariate statistical evaluation of dissolved trace elements and a water quality assessment in the middle reaches of Huaihe River, Anhui, China. Sci. Total Environ. 2017, 583, 421-431. [CrossRef]

56. Wei, L.; Huang, C.; Zhong, Y.; Wang, Z.; Hu, X.; Lin, L. Inland waters suspended solids concentration retrieval based on PSO-LSSVM for UAV-borne hyperspectral remote sensing imagery. Remote Sens. 2019, 11, 1455. [CrossRef]

57. Viscarra Rossel, R.; Behrens, T. Using data mining to model and interpret soil diffuse reflectance spectra. Geoderma 2010, 158, 46-54. [CrossRef]

58. Walczak, B.; Massart, D.L. The radial basis functions-Partial least squares approach as a flexible non-linear regression technique. Anal. Chim. Acta 1996, 331, 177-185. [CrossRef] 
59. Field, A.P. Discovering Statistics Using IBM SPSS Statistics; Sage Publication: London, UK, 2009.

60. Mustapha, A.; Aris, Z.A. Multivariate statistical analysis and environmental modeling of heavy metals pollution by industries. Pol. J. Environ. Stud. 2012, 21, 1359-1367.

61. Pallant, J. SPSS Survival Manual: A Step by Step Guide to Data Analysis Using SPSS for Windows Version 15; Open University Press: Berkshire, UK, 2007; p. 165.

62. Chen, J.; Lu, J. Effects of land use, topography and socio-economic factors on river water quality in a mountainous watershed with intensive agricultural production in East China. PLoS ONE 2014, 9, e102714. [CrossRef] [PubMed]

63. Venables, W.N.; Ripley, B.D. Modern Applied Statistics with S, 4th ed.; Springer: New York, NY, USA, 2002.

64. APHA. Standard Methods for the Examination of Water and Wastewater; American Public Health Association: Washington, DC, USA, 2012.

65. Cude, C.G. Oregon water quality index a tool for evaluating water quality management effectiveness. J. Am. Water Resour. Assoc. 2001, 37, 125-137. [CrossRef]

66. Simsek, C.; Gunduz, O. IWQ index: A GIS-integrated technique to assess irrigation water quality. Environ. Monit. Assess. 2007, 128, 277-300. [CrossRef]

67. Todd, D.K. Groundwater Hydrology; Wiley: New York, NY, USA, 1980.

68. Richards, L.A. Diagnosis and Improvement of Saline and Alkali Soils; U.S. Department of Agriculture: Washington, DC, USA, 1954.

69. Doneen, L.D. Notes on Water Quality in Agriculture; Department of Water Science and Engineering, University of California: California, CA, USA, 1964.

70. Kelley, W.P. Permissible composition and concentration of irrigated waters. Proc. Am. Soc. Civ. Eng. 1940, 66, 607-613.

71. Gad, M.; Elsayed, S.; Moghanm, F.S.; Almarshadi, M.H.; Alshammari, A.S.; Khedher, K.M.; Eid, E.M.; Hussein, H. Combining Water Quality Indices and Multivariate Modeling to Assess Surface Water Quality in the Northern Nile Delta, Egypt. Water 2020, 12, 2142. [CrossRef]

72. Vasques, G.M.; Grunwald, S.; Sickman, J.O. Comparison of multivariate methods for inferential modeling of soil carbon using visible/near-infrared spectra. Geoderma 2008, 146, 14-25. [CrossRef]

73. FAO. Water Quality Guidelines for Agriculture, Surface Irrigation and Drainage; FAO: Rome, Italy, 1985.

74. Vetrimurugan, E.; Elango, L. Seasonal and spatial variation in magnesium and chloride concentration in groundwater of deltaic regions of Kumbakonam, Nannilam and Karaikal, Tamil Nadu. Indian J. Environ. Prot. 2007, 27, 987-995.

75. El-Bana, T.A. Agro-Ecological Assessment of Land and Water Resources Norther Nile Delta: A Case Study in Kafr El-Sheikh Governorate. Master's Thesis, Alexandria University, Alexandria, Egypt, 2003.

76. El-Bana, T.A.; Gaber, H.M.; Bahnassy, M.H.; Suliman, A.S. Quality assessment of water resources in Northern Nile Delta: A case study in Kafr El-Sheikh Governorate. Egypt. J. Soil Sci. 2006, 46, 409-423.

77. Srinivasamoorthy, K.; Chidambaram, S.; Prasanna, M.V.; Vasanthavihar, M.; Peter, J.; Anandhan, P. Identification of major sources controlling groundwater chemistry from a hard rock terrain-A case study from Mettur taluk, Salem district, Tamil Nadu, India. J. Earth Syst. Sci. 2008, 117, 49-58. [CrossRef]

78. Obeidatt, A.; Alawneh, M. Hydrochemistry and groundwater quality assessment in Mafraq Province, Jordan. Open Access Libr. J. 2019, 6, 1-10. [CrossRef]

79. Subrahmanyam, K.; Yadaiah, P. Assessment of the impact of industrial effluents on water quality in Patancheru and environs, Medak district, Andhra Pradesh, India. Hydrogeol. J. 2001, 9, 297-312. [CrossRef]

80. Masoud, A.H.; El-Fakharany, I.I.; Abd El-Razik, M.A.S. Monitoring of some agrochemical pollutants in surface water in Kafr El-Sheikh Governorate. J. Pest. Cont. Environ. Sci. 2007, 15, 21-41.

81. Avila, P.F.; Oliveira, J.S.; da Silva, E.F.; Fonseca, E.C. Geochemical signatures and mechanisms of trace elements dispersion in the area of the Vale das Gatas mine (Northern Portugal). J. Geochem. Explor. 2005, 85, 17-29. [CrossRef]

82. Khan, M.Y.; Gani, K.M.; Chakrapani, G.J. Spatial and temporal variations of physicochemical and heavy metal pollution in Ramganga River-A tributary of River Ganges, India. Environ. Earth Sci. 2017, 76, 231. [CrossRef]

83. Purushothman, P.; Rao, M.S.; Kumar, B.; Rawat, Y.S.; Krishan, G.; Gupta, S.; Marwah, S.; Bhatia, A.K.; Kaushik, Y.B.; Angurala, M.P.; et al. Drinking and irrigation water quality in Jalandhar and Kapurthala Districts, Punjab, India: Using hydrochemistry. Int. J. Earth Sci. Eng. 2012, 5, 1599-1608. 
84. Saleh, A.; Al-Ruwaih, F.; Shehata, M. Hydrogeochemical processes operating within the main aquifers of Kuwait. J. Arid Environ. 1999, 42, 195-209. [CrossRef]

85. Sundaray, S.K.; Nayak, B.B.; Bhatta, D. Environmental studies on river water quality with reference to suitability for agricultural purposes: Mahanadi river estuarine system, India-A case study. Environ. Monit. Assess. 2009, 155, 227-243. [CrossRef]

86. Srinivasamoorthy, K.; Gopinath, M.; Chidambaram, S.; Vasanthavigar, M.; Sarma, V.S. Hydrochemical characterization and quality appraisal of groundwater from Pungar sub basin, Tamilnadu, India. J. King Saud Uni. Sci. 2014, 26, 37-52. [CrossRef]

87. Subramani, T.; Elango, L.; Damodarasamy, S.R. Groundwater quality and its suitability for drinking and agricultural use in Chithar River Basin, Tamil Nadu, India. Environ. Geol. 2005, 47, 1099-1110. [CrossRef]

88. Suarez, D.L.; Wood, J.D.; Lesch, S.M. Effect of SAR on water infiltration under a sequential rain-irrigation management system. Agric. Water Manag. 2006, 86, 150-164. [CrossRef]

89. Tiwari, T.N.; Manzoor, A. River pollution in Kathmandu valley (Nepal) suitability of river water for irrigation. Indian J. Environ. Prot. 1988, 8, 269-274.

90. Arumugam, K.; Elangovan, K. Hydrochemical characteristics and groundwater quality assessment in Tirupur Region, Coimbatore District, Tamil Nadu, India. Environ. Geol. 2009, 58, 1509-1520. [CrossRef]

91. Kelley, W.P. Alkali soils: Their Formation, Properties and Reclamation; Reinhold: New York, NY, USA, 1951.

92. Kumar, M.; Kumari, K.; Ramanathan, A.; Saxena, R. A comparative evaluation of groundwater suitability for irrigation and drinking purposes in two intensively cultivated districts of Punjab, India. Environ. Geol. 2007, 53, 553-574. [CrossRef]

93. Hem, J.D. Study and interpretation of the chemical characteristics of natural water. USGS Water Supply Paper 1995, 264, 117-120.

94. Ravikumar, P.; Somashekar, R.K.; Angami, M. Hydrochemistry and evaluation of groundwater suitability for irrigation and drinking purposes in the Markandeya River basin, Belgaum District, Karnataka State, India. Environ. Monit. Assess. 2011, 173, 459-487. [CrossRef]

95. Sudhakar, A.; Narsimha, A. Suitability and assessment of groundwater for irrigation purpose: A case study of Kushaiguda area, Ranga Reddy district, Andhra Pradesh, India. Adv. Appl. Sci. Res. 2013, 4, 75-81.

96. Ahmed, U.; Mumtaz, R.; Anwar, H.; Shah, A.A.; Irfan, R.; García-Nieto, J. Efficient water quality prediction using supervised machine learning. Water 2019, 11, 2210. [CrossRef]

97. Chen, W.B.; Liu, W.C. Water quality modeling in reservoirs using multivariate linear regression and two neural network models. Adv. Artif. Neural Syst. 2015, 2015, 521721. [CrossRef]

98. Wang, Y.; Yuan, Y.; Pan, Y.; Fan, Z. Modeling daily and monthly water quality indicators in a canal using a hybrid wavelet-based support vector regression structure. Water 2020, 12, 1476. [CrossRef]

Publisher's Note: MDPI stays neutral with regard to jurisdictional claims in published maps and institutional affiliations.

(C) 2020 by the authors. Licensee MDPI, Basel, Switzerland. This article is an open access article distributed under the terms and conditions of the Creative Commons Attribution (CC BY) license (http://creativecommons.org/licenses/by/4.0/). 